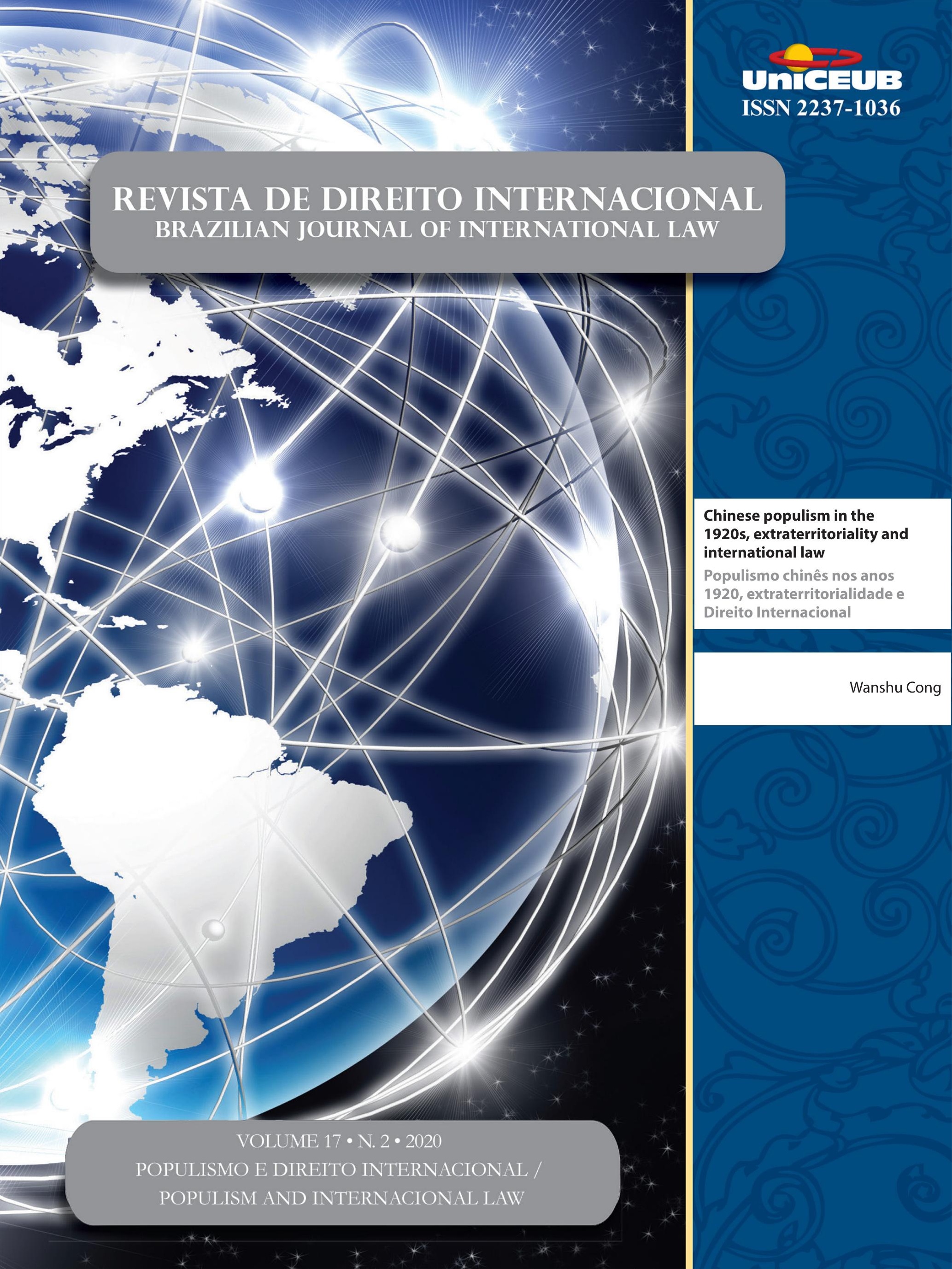




\section{Sumário}

I. CRônicas

A Favor de uma Corte Latino-Americana de Justiça ..................................................... 3 Nitish Monebhurrun

Sobre A SOluÇão JUdicial de CONTROvérsias Na AMÉRICA LATINA 7 Lucas Carlos Lima

A Favor de uma Corte Latino-Americana de Justiça - Uma Reação sobre a Legalidade e A Legitimidade De Seu Desenho Institucional............................................................15

Arthur Roberto Capella Giannattasio

O Estudo do Direito Internacional sob uma Nova Perspectiva: Nossa Experiência na Philip C. Jessup International Moot Court Competition............................................20 Ana Vitória Muniz Bokos, Igor Medeiros Maia, Jefferson Seidy Sonobe Hable, Gabriel de Oliveira Borba, Gilda Nogueira Paes Cambraia e Nayara Lima Rocha Da Cruz

Revisión de laudos de arbitrajes de inversión 2019: I Encuentro Anual (Santiago de

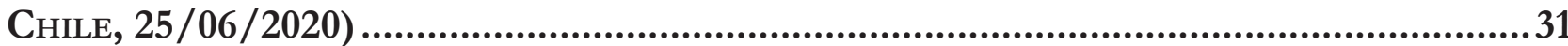
Andrés Delgado Casteleiro e Ivette Esis

II. Dossiê: Populismo e Direito Internacional / Populism and Internatio-

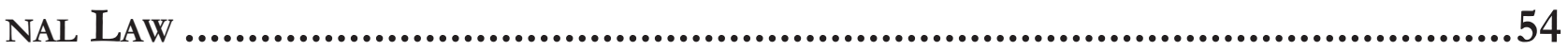

Editorial: Populism and International Law: Global South Perspectives .56 Lucas Lixinski e Fabio Morosini

Editorial: Populismo e Direito Internacional: Perspectivas do Sul Global .61 Lucas Lixinski e Fabio Morosini 
Between Science and populism: the Brazilian Response to COVID-19 from the Perspective of the legal determinants of Global Health

Deisy de Freitas Lima Ventura e Jameson Martins

Populism, ENVIronmental LAW, AND THE POST-PANDEMiC ORDER Alessandra Lehmen

Populism and the Evangelical church in Latin America: how anti-LGBTI forces TRIED TO STOP THE COLOMBIAN PEACE AGREEMENT Julia Assmann de Freitas Macedo e Fabrízio Conte Jacobucci

“Deus EM Davos": o Direito INTERnACIONAL ENTRE REACIONÁRIOS E NEOLIBERAIS NO GOVERNO BOLSONARO 121

Lucas Tasquetto e João Roriz

CHINESE POPULISM IN THE 1920s, EXTRATERRITORIALITY AND INTERNATIONAL LAW 139 Wanshu Cong

CONCEPTUALIZING UNILATERALISM, FRAGMENTATIONISM AND STATISM IN A POPULISM CONTEXT: A RISE OF POPULIST INTERNATIONAL LAW? 162 Wei Shen e Carrie Shu Shang

AUTONOMÍA ADMINISTRATIVA SIN AUTONOMÍA POLÍTICA: LA APLICACIÓN DEL MODELO "UN PAÍS dos SISTEMAs" eN HoNg Kong 186 Juan Enrique Serrano Moreno

III. Artigos sobre outros temas...................................................... 197

Um TWAiler entre nós? As contribuições de Celso Duvivier de Albuquerque Mello PARA O DIREITO INTERNACIONAL (CRÍTICO) NO BRASIL .................................................... 199

Fabio Morosini e Matheus Leichtweis

DEMOCRACIES IN DANGER: ARE JUDICIAL DIALOGUES MEANS TO REFRAIN SETBACKS IN LATIN America?.

Melina Girardi Fachin e Bruna Nowak 


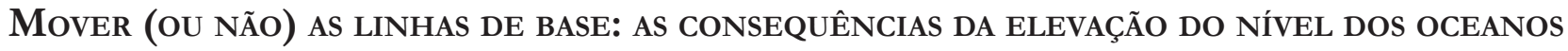
SOBRE AS ZONAS MARÍTIMAS DOS PEQUENOS ESTADOS INSULARES EM DESENVOLVIMENTO E AS ALTERNATIVAS JURÍDICAS PARA REDUZIR SEUS IMPACTOS

Alexandre Pereira da Silva

A mineração em águas profundas no Pacífico 263 Pierre-Jean Bordahandy

Dual Nationality and International Law in times of Globalization. Challenges and Opportunities for Consular Assistance and Diplomatic Protection in RECENT CASES. 288

Walter Arevalo-Ramirez e Robert Joseph Blaise Maclean

Expulsion of aliens: the application of International Law by Chilean Superior Courts 309

Regina Ingrid Díaz Tolosa

O TIPO PENAL BRASILEIRO DE PROMOÇÃo DE MIGRAÇÃO ILEGAL E O PRINCÍPIO DA NÃO CRIMINALIZAÇÃo DA MOBILIDADE HUMANA

Regina Cândido Lima e Silva Santos e Deilton Ribeiro Brasil

INDICADORES TRANSNACIONAIS DE CORRUPÇÃO AMBIENTAL: A OPACIDADE NA TRANSPARÊNCIA INTERNACIONAL

Márcio Ricardo Staffen

SubTRAÇÃo INTERNACIONAL DE CRIANÇAS: ANÁLISE DAS EXCEÇÕES AO RETORNO IMEDIATO DO MENOR À RESIDÊNCIA HABITUAL E CRÍTICA AO ENQUADRAMENTO DA VIOLÊNCIA DOMÉSTICA COMO FLEXIBILIDADE PERMISSIVA

Vivian Daniele Rocha Gabriel

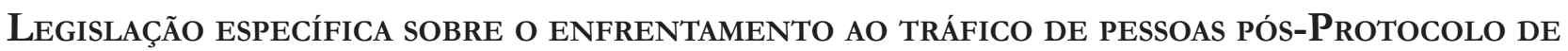
Palermo (2000): análise do Estado de Moçambique 383

Mercia Cardoso de Souza, Guirino Dinis José Nhatave e Francisco Horácio da Silva Frota 
IV. Artigos traduzidos

DIREITO INTERNACIONAL DO RECONHECIMENTO

Emmanuelle Tourme-Jouannet e Tradutor: Ademar Pozzatti Junior

V. RESENHAS

Fabio Costa Morosini, Gabriel Lee Mac Fadden Santos, Valentina Fonseca da Luz e Vinicius Tejadas Maia 


\title{
Chinese populism in the 1920s, extraterritoriality and international law*
}

\author{
Populismo chinês nos anos 1920, \\ extraterritorialidade e Direito Internacional
}

Wanshu Cong**

\begin{abstract}
Recent scholarship and commentaries on populism and international law often focus on the rise of right-wing populist regimes in contemporary politics. This paper invites a shift of attention to populism in the (semi)colonies in the process of national liberation and anticolonialism, in order to achieve a more historically and socially informed understanding about the relationship between populism and international law. The paper chooses the populist movements in China against extraterritoriality and imperialism in the 1920s. I will ask what particular frustrations and ideologies motivated the populist movements in the 1920s. Drawing on Laclau's theory, I will analyse why and how exactly these movements were populist. In addition, the direct and indirect consequences of the Chinese populism will be examined to understand its ramifications not only on the revision of unequal treaties and the dismantling of extraterritoriality, but more broadly on the development of international law. Using this historical episode, the paper highlights populism's emancipatory potential of mobilising resistance against repression and correcting systemic injustice, as well as the intrinsic ambivalence of such potential.
\end{abstract}

Keywords: Populism, anti-imperialism, nationalism, extraterritoriality, treaty revision

\section{Resumo}

Estudos e comentários recentes sobre populismo e direito internacional focalizaram na ascensão de regimes populistas de direita na política contemporânea. Este artigo convida a uma mudança de atenção para o populismo nas (semi) colônias no processo de libertação nacional e anticolonialismo, a fim de alcançar uma compreensão mais histórica e socialmente informada sobre a relação entre populismo e direito internacional. $\mathrm{O}$ artigo escolhe os movimentos populistas na China contra a extraterritorialidade e o imperialismo na década de 1920 problematizando como as frustrações e as ideologias específicas motivaram os movimentos populistas na década de 1920. Com base na teoria de Laclau, analisarei por que e como exatamente esses movimentos eram populistas. Além disso, as consequências diretas e indiretas do populismo chinês serão examinadas para entender suas ramificações não

* Wanshu Cong received a D.C.L. from McGill University Faculty of Law in February 2020 and holds an LL.M from the Geneva Academy of International Humanitarian Law and Human Rights (2014). Email: Wanshu. Cong@eui.eu
Recebido em 21/03/2020 Aprovado em 27/08/2020 
apenas na revisão de tratados desiguais e no desmantelamento da extraterritorialidade, mas de forma mais ampla no desenvolvimento do direito internacional. Usando esse episódio histórico, o artigo destaca o potencial emancipatório do populismo de mobilizar a resistência contra a repressão e corrigir a injustiça sistêmica, bem como a ambivalência intrínseca de tal potencial

Palavras-chave: Populismo. Anti-imperialismo. Nacionalismo. Extraterritorialidade. Revisão de tratado.

\section{Introduction}

The emergence of populist governments in various parts of the world in recent years has led to renewed interest in studying "populism", the causes of populism and how it should be responded. Located in the conjuncture of the rise of populist governments and various forms of "crisis" of the model of liberal democracy, ${ }^{1}$ the mainstream literature on populism has mainly paid attention to the right-wing populism and often tends to merge populism with ethno-nationalism, isolationism and xenophobia, hence, making "populism" largely a pejorative term. ${ }^{2}$ Despite the relatively common acknowledgement that populism is easily attached to variated ideologies, ${ }^{3}$ relatively less studies have been made to the cases where populism played a more progressive role throughout the $20^{\text {th }}$ century. ${ }^{4}$ Even less attempt was

DOYLE, O. et al. Populism: a health check for constitutional democracy? German Law Journal, v. 20, n. 401, 2019; WALKER, N. Populism and constitutional tension. International Journal of Constitutional Law, v. 17, n. 515, 2019.; KUO, M-S. Against Instantaneous Democracy. International Journal of Constitutional Law, v. 17, n.

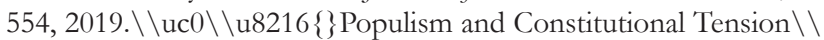
uc0 $\backslash \backslash \mathrm{u} 8217\{\}$ (2019

2 EATWELL, R.; GOODWIN, M. National populism: the revolt against liberal democracy. London: Penguin UK, 2018; BUGARIC, B. Central Europe's descent into autocracy: a constitutional analysis of authoritarian populism. International Journal of Constitutional Law, v. 17, n. 2, p. 597-616, jul. 2019; SCHEPPELE, K. L. The opportunism of populists and the defense of constitutional liberalism. German Law Journal, v. 20, n. 314, 2019.

3 MUDDE, C.; KALTWASSER, C. R. Populism: a very short introduction. Oxford: Oxford University Press, 2017.

4 HOWSE, R. Epilogue: in defense of disruptive democracy: a critique of anti-populism. International Journal of Constitutional Law, v. 17, n. 641, 2019; MCKNIGHT, D. Populism Now!: the case for progressive populism paperback. Australian: University of New South Wales Press, 2018; BUGARIC, B. The two faces of populism: between authoritarian and democratic populism. German Law Journal, v. 20, n. 3, p. 390-400, abr. 2019. \{\\i\{\} Populism Now! \} ReadHow- devoted to reclaiming and taking "populism" back from the right-wingers and to reutilising it for correcting the structurOal deficits of liberal democracy. ${ }^{5}$ This tendency of considering populism as mainly right-wing can also be found in the scholarship of international law, which often associates populism with the backlashes against multilateralism and international cooperation and sees populism as threatening and undermining the liberal international legal order. ${ }^{6}$

YouWant.com, Limited 2018

5 MOUFFE, C. For a Left Populism. Rio de Janeiro: Verso Books, 2018; MCKNIGHT, D. Populism Now!: the case for progressive populism paperback. Australian: University of New South Wales Press, 2018. " a left-populist strategy could bring together the manifold struggles against subordination, oppression and discrimination. This strategy acknowledges that democratic discourse plays a crucial role in the political imaginary of our societies. And through the construction of a collective will, mobilizing common affects in defence of equality and social justice, it will be possible to combat the xenophobic policies promoted by right-wing populism. In redrawing political frontiers, this \"populist moment \" points to a \"return of the political $\backslash$ " after years of postpolitics. A return may open the way for authoritarian solutions--through regimes that weaken liberal-democratic institutions--but it could also lead to a reaffirmation and extension of democratic values",'ISBN":"978-1-78663-755-0","'language ":"en","note":"'Google-Books-ID: ccNfDwAAQBAJ","numberof-pages":"113","publisher":,"Verso Books","source":"Google Books","title":"For a Left Populism"," author":[\{“family":"Mo uffe","given":"Chantal"\}],"issued":\{“date-parts":[[“2018”]]\}\}\} , “"id":2405,"uris":[“http://zotero.org/users/3476091/items / NW2CW39E”],"uri”:[“"http://zotero.org/users/3476091/items/ NW2CW39E”],"itemData":\{“id":2405,"type":”book","abstract":” Populism can be a dirty word. Brexit and the election of Donald Trump have certainly given it a bad name. But rather than associating it with demagoguery and exclusion, might we better see it as a backlash against free market globalisation? Might it be harnessed as a positive force able to thrive in difficult times? This timely and persuasive book exposes the failures of globalisation: greedy banks, predatory privatisation, corporate tax avoidance and a growing underclass of temporary overseas workers. David McKnight argues that a progressive populism could address the genuine economic grievances of everyday people, without scapegoating immigrants or ethnic minorities. In fact, a progressive form of populism may be the best way of defeating the racist backlash of right-wing populism. It may also be the best way to save the planet. In a world where the super-rich get richer, one that is charged with hate-filled language as people look for someone else to blame, the case for progressive populism must be heard. This important book helps give it voice.",'ISBN":,'978-1-5252-7708-5",'”language":"'en","'note ":"Google-Books-ID: JiZguQEACAAJ","number-of-pages":"'234" ,"publisher":"ReadHowYouWant.com, Limited","source":"'Google Books","title":’Populism Now!',"author":[\{“family":"McKnight" ,"given":"David"\}],"issued": \{“date-parts":[[“2018”,4,27]]\}\}\}],"sc hema":"https://github.com/citation-style-language/schema/raw/ master/csl-citation.json"'

6 POSNER, E. A. Liberal Internationalism and the Populist Backlash. Public Law and Legal Theory Working Papers, v. 66, 2017.; KRIEGER, H. Populist Governments and International Law. European Journal of International Law, v. 30, n. 971, 2019; WUERTH, 
The mainstream treatment of "populism" is critiqued by Schwöbel-Patel as very much Western-centric and ahistorical. ${ }^{7}$ To rethink populism and to revive its progressive potential to correct the deficits of the liberal international legal order require the broadening of theoretical horizons and invite new engagements with history. The critique of Western-centrism raises important questions about the experiences of populism in the Third-World countries and the influences of those experiences on their perceptions and practices of international law. Countries of the Global South, being the late comers to the club of the "civilized nations", have made crucial efforts (such as the New International Economic Order ${ }^{8}$ and the Bandung Declaration?) to call up international solidarity and redistribute political and economic powers to make international legal order more just, fair and inclusive. So far, studies on Third World populism have been focusing on the postcolonial era and, in particular, the trials and errors of the populist leaders in Latin America. ${ }^{10}$ What is surprisingly less discussed in the current studies about populism and international law is the populist movements in other colonies and semi-colonies before fully achieving sovereign independence. Often closely related to the movements of national liberation and anti-imperialism, the experiences of (semi)colonies had lasting impacts on the development of international law and the struggles for global justice in the postcolonial era. Studying these movements, and in particular, their construction

I. International Law in the Post-Human Rights Era. Texas Law Review, v. 96, n. 279, 2017.; ROBERTS, A. Is International Law International? Oxford: Oxford University Press, 2017.; HOSTOVSKY BRANDES, T. International law in domestic courts in an era of populism. International Journal of Constitutional Law, v. 17, n. 576,

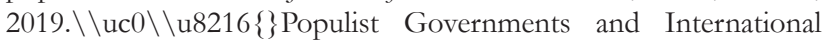

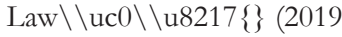

SCHWÖBEL-PATEL, C. Populism, international law and the end of keep calm and carry on lawyering. In: NIJMAN, J. E.; WERNER, W. G. (ed.). Netherlands Yearbook of International Law 2018. Berlin: TMC Asser Press, 2019. v. 49.

8 GILMAN, N. The new international economic order: a reintroduction. Humanity: An International Journal of Human Rights, Humanitarianism, and Development, v. 6, n. 1, 2015.

ESLAVA, L. et al. Bandung, global history, and international law: critical pasts and pending futures. Cambridge: Cambridge University Press, 2017.

10 RODILES, A. Is There a "Populist" International Law (in Latin America)? In: NIJMAN, J. E.; WERNER, W. G. (ed.). Netherlands Yearbook of International Law 2018. Berlin: TMC Asser Press, 2019. v. 49.; DE LA TORRE, C. Populism in Latin America. Oxford: Oxford University Press, 2017. Available in: https://www. co /10.1093/oxfordhb/9780198803560.001.0001/oxfordhb9780198803560-e-8 Accessed on: 21 Feb. 2020. of "the people" and political frontiers, their naming of "the enemy", and their imaginations about the world order would offer insights not only about the colonial shadow of international law (which has been a significant topic of study in the recent international legal scholarship ${ }^{11}$ ), but more importantly - for the purpose of better understanding populism and international law - how "the political logic" of populism has influenced the modern international law.

This paper intervenes in the current studies on Third World populism and international law by looking into the populist movements in China in the 1920s and the ways in which they had contributed to the dismantling of extraterritoriality in China. The 1920s was a unique decade for both China and international law. For international law, the decade following the First World War saw the Versailles-Washington international system, an ambitious but frail system comprising of the "civilized states" who uneasily treated each other as equals and coordinated through the League of Nations. ${ }^{12}$ The co-

11 BENTON, L. Made in empire: Finding the history of international law in imperial locations: introduction. Leiden Journal of International Law, v. 31, n. 3, p. 473-478, 2018; VON BERNSTORFF, J.; DANN, P. (ed.). The Battle for International Law: South-North perspectives on the Decolonization Era. Oxford: Oxford University Press, 2019.; CHIMNI, B. S. Capitalism, imperialism, and international law in the twenty-first century. Oregon Review of International Law, v. 14, n. 17, 2012; ANGHIE, A. Imperialism, sovereignty and the making of international law. Cambridge: Cambridge University Press, 2007.

12 JOUANNET, E. The liberal-welfarist law of nations: a history of international law. Cambridge: Cambridge University Press, 2012; KINGSBURY, B. Sovereignty and inequality. European Journal of International Law, v. 9, n. 599, 1998.international law has always been a welfarist law, too. Emerging in eighteenth-century Europe, it soon won favour globally. Not only did it minister to the interests of states and their concern for stability, but it was also an interventionist law designed to ensure the happiness and well-being of peoples. Hence international law initially served as a secularised eschatological model, replacing the role of religion in ensuring the proper ordering of mankind, which was held to be both one and divided. That initial vision still drives our post-Cold War globalised world. Contemporary international law is neither a strictly welfarist law nor a strictly liberal law, but is in fact a liberalwelfarist law. In the conjunction of these two purposes lies one of the keys to its meaning and a partial explanation for its continuing ambivalence.",'ISBN":"'978-1-107-37953-4",'”language":"en","'not e":"'Google-Books-ID: OEMhAwAAQBAJ","number-of-pages":", 327","publisher":"'Cambridge University Press","source":"Google Books","title":"The Liberal-Welfarist Law of Nations: A History of International Law","title-short":"'The Liberal-Welfarist Law of Nations","'author":[\{“family”:’’Jouannet","given”:’'Emmanu elle"\}],"issued”: \{“date-parts":[[“2012”,1,26]]\}\},"locator":"130138 " $\}$, “id":2455,"uris":[“http:// zotero.org/users/3476091/ items/EPMM2AXZ”],"uri”:["http://zotero.org/users/3476091/ items/EPMM2AXZ”],"itemData": \{“id”:2455,"type":"article- 
loniality of international law was still maintained by the Western "great powers", and nevertheless, was challenged by two powerful and completely different world views and ideologies: the vision of a liberal world order offered by Woodrow Wilson on the one hand, and the vision of proletarian international revolution started from Russia on the other hand. Both world views and ideologies inspired and mobilized the peoples in the (semi)colonies to demand national self-determination and independence. Waves of mass political and military upheavals in the peripheries seemed to bring the old world of imperial rule to the verge of collapse.

For China, characterized as "semi-colonial" and "semi-feudal", ${ }^{13}$ the Chinese society in the 1920 s also saw various emancipatory ideas and practices of different ideologies, such as socialism, communism, and liberalism, etc. For a short period, these ideas and ideologies, despite their differences, coalesced around a common enemy, i.e., the imperialists. And one of the major specific targets of the anti-imperialist movements was the system of extraterritoriality. The system of extraterritoriality, which originated from a series of unequal treaties between China and the foreign powers since the mid- $19^{\text {th }}$ century, had already evolved into a full-fledged political-juridical system which suspended and displaced the Chinese jurisdiction on China's own territories. The most vivid objectification, and indeed the territorialisation, of such a political-juridical system of foreign rule, was the establishment of foreign concessions and settlements in treaty ports on the basis of various kinds of land lease agreements. From the mid-1840s to 1902, there were about 27 foreign concessions in China. Signifying the great violation of China's sovereignty, the system of extraterritoriality, as objectified into the exceptional spaces of concessions and settlements, was the prime objective of China's emancipation in the 1920s.

journal","'container-title":'"European Journal of International Law","language":"en","page":"599-625",,"source":"'Zotero","title", :"Sovereignty and Inequality","volume":,"9,,"author":[\{“family":", Kingsbury","given":"Benedict"\}],"issued": \{“date-parts":[[“1998”] ]\} \},"locator":"603-604"'\}],"schema":"https://github.com/citationstyle-language/schema/raw/master/csl-citation.json"\}

13 For example, Chen Duxiu, one of the Chinese leading intellectuals and the co-founder of Chinese Communist Party, wrote that "the National Revolution has two meanings: national revolution and democratic revolution, namely, the overthrow of foreign imperialism and the native semi-feudal forces." DUXIU apud HAN, X. Chinese Discourses on the Peasant, 1900-1949. New York: SUNY Press, 2012.
China had been requesting the abolition of extraterritoriality since the late Qing dynasty. By the second half of the 1910s, as the treaty powers were fighting the First World War in Europe, which drastically changed the power dynamic in China, the demand of abolishing extraterritoriality and fully recovering the sovereignty of China emerged from various parts of the Chinese society and became especially urgent. From the Paris Peace Conference to the Washington Conference, the Chinese delegations tried to put this demand on the agenda. Motivated by Wilson's Fourteen Points, the Chinese government hoped to gather sympathies among the world leaders and persuade the treaty powers in bloc to relinquish extraterritoriality all together. ${ }^{14}$ This, however, was wishful thinking. The long list of proposals made by the Chinese Delegation at the Paris Peace Conferen$\mathrm{ce}^{15}$ was largely put aside, as the Conference was mainly concerned about the postwar situation in Europe. ${ }^{16}$ The Chinese proposals were, however, included in the mandates of the Washington Conference two years later. What resulted from the Washington Conference was at best a mixed blessing. The nine-power treaty established the principle of cooperation in China, and the other eight powers (i.e., the US, the UK, France, Italy, Portugal, Japan, Netherland and Belgium) were to respect China's sovereignty, independence and integrity and to provide an environment for China to develop a stable government. ${ }^{17}$ However, in terms of the abrogation of extraterritoriality, the Washington Conference did not achieve any concrete promises, but decided to establish a commission of inquiry to study the practice of extraterritoriality in China and that the findings of that commission would not be binding on the other eight powers at the Conference. ${ }^{18}$ There were, then, unpre-

14 YONGJIN, Z. China in the International System, 1918-20: the middle kingdom at the periphery. London: Palgrave Macmillan UK, 1991.

15 The Chinese Memorandum submitted to the Paris Peace Conference includes these requests: the renunciation of the spheres of influences in China, foreign troops and police, and foreign post offices, the relinquishment of consular jurisdictions, leased territories and concessions and settlements, and the denunciation of the conventional tariff. YONGJIN, Z. China in the International System, 1918-20: the middle kingdom at the periphery. London: Palgrave Macmillan UK, 1991.

16 YONGJIN, Z. China in the International System, 1918-20: the middle kingdom at the periphery. London: Palgrave Macmillan UK, 1991.

17 UNITED STATES. Conference on the Limitation of Armament. Washington, 1921. Available in: https://www.ibiblio.org/pha/prewar/1922/nav_lim.html Accessed on: 3 Mar. 2020.

18 See, Resolution regarding Extraterritoriality in China, UNITED 
cedented feelings of injustice in China toward the extraterritoriality system and international law. The origin of the extraterritorial system - the unequal treaties that China signed after losing wars to the foreign powers of course, remained a major source of the national grievance. The grievance was, however, also exacerbated by the failure of the high hope about the benevolence of the imperial powers and the Wilsonian world order. International conferences offered no level playing fields for China, only a "probationary" member of the Family of Nations, ${ }^{19}$ to negotiate with the foreign powers. A different route to the dismantling of extraterritoriality needed to be taken.

The disappointment regarding the prospect of fully recovering China's sovereignty through formal international participation had made the Chinese government (the Beijing Government, which was, then, internationally recognized) change strategy. Instead of seeking the agreements of all treaty powers in international conferences, the Beijing Government started to approach each treaty power and to address the issue of extraterritoriality through bilateral negotiations on treaty revision. This was made possible also by the fact that several treaties signed in the late $19^{\text {th }}$ century were approaching to expiration, ${ }^{20}$ which made the legal bases of the extraterritorial system uncertain. In addition, the Beijing Government also actively invoked the doctrine of Rebus Sic Stantibus to seek treaty revisions. ${ }^{21}$ While the Beijing Government achieved some important progresses through bilateral negotiations, it remained especially difficult to convince the United Kingdom, who had the largest interest in China, to abandon extraterritoriality and to hand over its concessions to China. The difficulty was partly attributed to the civil war in China due to which the Beijing Government lost control over signi-

STATES. Conference on the Limitation of Armament. Washington, 1921. Available in: https://www.ibiblio.org/pha/pre-war/1922/nav_lim. html Accessed on: 3 Mar. 2020.

19 YONGJIN, Z. China in the International System, 1918-20: the middle kingdom at the periphery. London: Palgrave Macmillan UK, 1991.

20 Sino-Belgium Treaty of November 2, 1865 expired on October 27, 1926; the Sino-France Treaty of April 25, 1886 expired on August 7, 1926, the Sino-Japan Treaty of July 21, 1896 expired on October 20, 1926, the Sino-Spain Treaty of October 10, 1864 expired on May 10, 1927.

21 TSENG, Y-H. The termination of unequal treaties in international law: studies in comparative jurisprudence and Conventional Law of Nations. Pequin: The Commercial Press, Ltd, 1931. Available in: https://heinonline.org/HOL/P?h=hein.hoil/trmunql0001\&i=75 Accessed on: 3 Mar. 2020. ficant parts of the Chinese territories. Taking advantage of the situation of the civil war, the British claimed that while it was prepared to have friendly negotiation with the Chinese government, such negotiation had to be done with a central government having the authority to represent the whole of China. ${ }^{22}$ This attitude, understandably, was considered by the Chinese society as disingenuous and distrustful. The frustration of the Chinese society was also redirected to the Beijing Government who accepted the terms of the Washington Conference and was attempting to negotiate with the UK. And the Beijing Government was criticized by the revolutionary parties as traitorous. ${ }^{23}$ Formal diplomatic process had, hence, reached a standstill. There was when the populist movements came in.

In the 1920s, the populist movements in China were founded in several different ideologies and led by different political parties, while sharing the common target of foreign imperialism, especially the British imperialism. The Guomindang (hereinafter, the "KMT"), the nationalist party under the leadership of Sun Yat-sen, established a regime in Guangzhou in 1923 and organized waves of nationalist mass movements by mobilizing young students and the petty bourgeoisies. The Chinese Communist Party (hereinafter, the "CPC") was also growing rapidly by marshaling the urban proletariats, such as industrial workers and coolies, and became an important political force. While against Bolshevism, Sun Yat-sen was inspired by the Russian Revolution and attracted by the influence of the Communist Party, especially its appeal to the proletariat masses. He, hence, initiated the first alliance with the CPC in 1924. A large revolutionary force against the foreign imperialism was formed to amalgamate nationalist movements and labour movements. Drawing on Ernesto Laclau's analysis of populism, I will explore the political logic of populism in these mass movements: the construction of a popular identity - "the people" - as fluid and internally split, the identification of the "enemy", the creation of a broad political frontier of antagonism which unified specific and heterogenous social demands, and the investment of affection and rhetoric in these movements.

22 CHAPMAN, H. O. The Chinese Revolution 1926-27: a record of the period under communist control as seen from the nationalist capital, Hankow. Edimburgo: Constable \& CO LTD, 1928.

23 TANG, Q. Treaty revision campaign of the Beijing Government, 19121928: out of the shadow of the 'Abrogation of Unequal Treaties'. Beijing: Social Sciences Academic Press, 2010. 
The paper will examine how the mass anti-imperialist movements in China provided leverage for China in the struggle of abolishing extraterritoriality. In the next section, I will look into four specific movements during the period of anti-foreign, and especially, anti-British imperialism. The first two cases concerned the mass strikes and anti-British boycotts in 1925 following the killings of Chinese workers and protestors. The other two incidents were mass actions specifically targeting the British concessions in Hankou and Jiujiang in the early January of 1927. In discussing these four cases, I will explain the populist logic therein by drawing mainly from Laclau's theory of populism (Section 3). In Section 4 , these mass movements will be studied in terms of their direct and indirect impacts on extraterritoriality. Directly, the populist movements, especially in the treaty ports and foreign concessions, resisted against and challenged the rule of foreign powers by way of open confrontation. Indirectly, those movements, by denouncing the Beijing Government and supporting the Nationalist Government, also changed the game of the negotiation on the treaty revision by the Beijing Government. The anti-imperialist frontier created by the KMT - CPC alliance had its internal contradictions and conflicts, which had led to a tragic crackdown against the communists by General Jiang Jieshi (also spelt as Chiang Kai-shek) in April 1927. In examining the selected cases of mass movements and their impacts on extraterritoriality, the study will highlight the ambivalence of populism, its progressive and emancipatory potential, as well as the fragility of its construction of "the people" and its political frontier. In studying this particular episode of populist movements in China, this paper aims to contribute to a subtler and more historically and socially informed understanding of populism and its relationship with international law.

\section{Populist anti-imperial movements in the 1920s China}

\subsection{The emergence of the anti-imperialist political frontier}

Starting from the late 1910s, anti-imperialism became a common cause that united different sectors and classes in the Chinese society and gradually formed a broad political alliance. Following the failure of the Chinese delegations at the Paris Peace Conference, on May 4 of 1919, ${ }^{24}$ a demonstration of some three thousand students took place in Beijing protesting against the Treaty of Versailles, which transferred the German cession of Jiaozhou and associated rights to Japan, and against Japan's Twenty-One Demands. Initiated by the students in Beijing, the movement spread to other major cities, such as Tianjin, Shanghai, Wuhan and Guangzhou, and gathered huge support from urban workers. Combining patriotism, nationalism and anti-imperialism, the protestors put forward the demands of protecting the sovereignty of China, punishing the traitorous ministers of the Beijing Government and refusing to sign the Treaty of Versailles. The movement brought tremendous pressure on the Beijing Government who, eventually, did not sign the Treaty. ${ }^{25}$

The May 4 Movement was the first time that students and workers allied in the Chinese political struggles. It was also the first time that the workers, a still very young class in China, explicitly articulated their demands and became a powerful agent of political struggle. Chinese workers employed in foreign factories had long been brutally abused and exploited by their employers. As documented by Chen Ta in a series of studies on the labour conditions in China in the 1920s, urban workers worked for between 12 to 16 hours a day for salaries too low to cover the rising living costs. In addition, workers were systematically subjected to racial discrimination and lacked basic guarantees for working safety and hygiene. Child labour was widely used from cotton mills to coalmines. ${ }^{26}$ The ideas of sovereignty and democracy which the workers learned from their student comrades in the May 4 Movement soon spread among them and were more concretely translated into various demands about labour rights to improve their socioeconomic conditions. They soon formed unions and held waves of strikes against the foreign exploiters in Hong Kong, Guangzhou, Changsha and Shanghai. It was documented that, for example, from 1918 to 1926,

\footnotetext{
24 YONGJIN, Z. China in the International System, 1918-20: the middle kingdom at the periphery. London: Palgrave Macmillan UK, 1991.

25 YONGJIN, Z. China in the International System, 1918-20: the middle kingdom at the periphery. London: Palgrave Macmillan UK, 1991.

26 CHEN, T. Labor Unrest in China. Monthly Labor Review, v. 13, n. 16, 1921; CHEN, T. Labor Conditions in China. Monthly Labor Review, v. 19, n. 5, p. 36-49, nov. 1924.
} 
the average annual number of recorded strikes was 136.88, involving almost 180,000 people per year from various sorts of industries. ${ }^{27}$

It is worth emphasizing the unique anti-imperialist character of the Chinese labour movement in the early 1920s. The Chinese economy had long been dominated by the foreign capital, due to a set of unequal treaties since the first Opium War. Massive amounts of foreign capital were invested to build factories, shipyards, coalmines and railways in China and significantly squeezed the room of development of the Chinese native capital. Hence, the workers' strikes, while making demands about the immediate improvement of their labour conditions, had their foreign exploiters the prime target of their movement. Due to the distorted structure of the capitalist economy in China, i.e., the domination by the foreign capital and the exploitation of the Chinese labourers by the foreign enterprises, the workers' movements not only addressed labour rights, but had a strong anti-imperialist tone. As Sun Yat-sen put it: "The difference between the Chinese workers and foreign workers lies in the fact that the latter are oppressed only by their own capitalists and not by those of other countries ...The Chinese workers are as yet not oppressed by Chinese capitalists ... They are oppressed by foreign capitalists." 28 This difference, as pointed out by Sun, also made possible the formation of alliance between the Chinese labourers and the nationalist bourgeoisies under the banner of anti-imperialism.

The unique anti-imperialist character of the Chinese labour movements made the workers a particularly powerful political force in the struggles for China's emancipation in the 1920s. While largest population of the oppressed masses in China was the peasants, the workers' organizations were far more developed than those of the peasants. ${ }^{29}$ The organization, concentration and determination of the workers made them especially politically conscious and responsive to the movements of other oppressed social groups which were devoted to the common cause of anti-imperialism. Specific anti-imperialist sentiments also often culminated

\footnotetext{
27 CHEN, T. Analysis of Strikes in China, from 1918 to 1926. London: Nabu Press, 2010.

28 ISAACS, H. The Tragedy of the Chinese Revolution. Chicago: Haymarket Books, 2009; YSUI, S-C. The Influence of the Canton-Moscow Entente upon Sun Yat-Sen's Political Philosophy. Chinese Social and Political Science Review, v. 18, n. 96, 1934.

29 CHEN, T. Analysis of Strikes in China, from 1918 to 1926. London: Nabu Press, 2010.
}

in sweeping strikes and boycotts, relayed by workers' organizations from one city to another. The following subsections look into four incidents during this period of mass movements which had significantly shaken the foreign, and especially, the British imperialism in China.

\section{2 "Down with Imperialism": From May 30 in Shanghai to the General Guangdong - Hong Kong Strike}

The May 30 Incident was one of the most important incidents in the anti-imperialist movements of the 1920s. It had major ramifications on the subsequent British policy toward China and the destiny of the extraterritorial system. From February to April of 1925, workers in Japanese cotton mills in Shanghai had been on strike and demanding for wage increases. The Japanese refused the demands, brutally beating the striking workers and killing a workers' representative, $\mathrm{Gu}$, on May $15^{\text {th }} \cdot{ }^{30}$ Over the rest month of May, students and workers in Shanghai had been seeking justice for Gu. Meanwhile, in Qingdao, a brutal crackdown by the pro-Japanese Chinese officials on the striking workers against the abuse at the Japanese mills happened on May $29^{\text {th }}$, leading to the deaths of eight workers and more than 70 arrests. ${ }^{31}$ On May $30^{\text {th }}$, more than two thousand students joined by the workers in Shanghai took to the street, protesting against the shooting down in Qingdao and the murder of Gu. Students delivered speeches and distributed the pamphlets in the train station and near the International Mixed Court in the Shanghai International Settlement. When the protestors gathered in front of a police station in the International Settlement, a British police officer ordered to open fire. As a result, thirteen protestors were killed. ${ }^{32}$ After the shooting, the Municipal Council of the International Settlement immediately declared the state of emergency. The Settlement was heavily guarded by machine guns, canons, cavalry and firetrucks. The Volunteer Corps and landed British marines searched several universities in the concession and dispelled students in the following days. ${ }^{33}$

\footnotetext{
30 SHANGHAI ACADEMY OF SOCIAL SCIENCES I OF H. Wu Sa Yundong Shi Liao. Shangai: Shanghai Remin Press, 1981. v. 1. 31 SHANGHAI ACADEMY OF SOCIAL SCIENCES I OF H. Wu Sa Yundong Sbi Liao. Shangai: Shanghai Remin Press, 1981. v. 1. 32 SHANGHAI ACADEMY OF SOCIAL SCIENCES I OF H. Wu Sa Yundong Sbi Liao. Shangai: Shanghai Remin Press, 1981. v. 1. 33 SHANGHAI ACADEMY OF SOCIAL SCIENCES I OF H. Wu Sa Yundong Sbi Liao. Shangai: Shanghai Remin Press, 1981. v. 1.
} 
The violent reaction of the British authorities in the International Settlement inflamed the masses. On June $2^{\text {nd }}$, the Shanghai General Labour Union declared a general boycott, demanding the punishment of the perpetrators and the compensation for the victims of the May 30 Incident, as well as the acknowledgement of the workers' right to form unions and the right to hold strikes. ${ }^{34}$ On June $7^{\text {th }}$, the Shanghai General Labour Union, the Shanghai Shopkeepers' Federation, the Shanghai Students' Federation, and the National Students' Federation formed a Committee of the Shanghai Workers', Merchants', and Students' Federation to organize and direct the strikes in Shanghai. The Committee came up with a 17 -point program in response to the May 30 Incident. In addition to the demands about punishment and compensation, the program demanded measures to alter the situation of the Shanghai International Settlement, including the revocation of the martial law, the withdrawal of the British marines, the abolition of the police station and the Volunteer Corps in the concession, and the release of the arrested Chinese protestors. The 17-point program also put forward further political demands on, inter alia, ensuring Chinese people's rights to freedom of speech, freedom of assembly and freedom of the press in the concession, abolishing extraterritoriality (mainly referred to the consular jurisdiction and the International Mixed Court), and returning the concession to Chinese administration upon the expiration of relevant treaties. ${ }^{35}$ The strong political tone of the demonstration in response to the May 30 Incident can be seen from a declaration made by the National Students' Federation that, "the murder and arrest of students and workers, the oppression of the freedom of expression and the heavy taxation were caused by the unequal treaties and the system of extraterritoriality." ${ }^{36}$ Following the direction of the Committee and the 17 -point program, a mass demonstration involving almost 200,000 people was held in Shanghai on June $11^{\text {th }} \cdot{ }^{37}$

\footnotetext{
34 ZHONGHUA, et al. (ed). Zhongguo Gonghui Lishi Wenxian (1921.7-1927.7). China: Gongren Press, 1958. Available in: https:// www.marxists.org/chinese/pdf/history_of_international/china/ g1.pdf Accessed on: 5 Mar. 2020.

35 SHANGHAI ACADEMY OF SOCIAL SCIENCES I OF H. Wu Sa Yundong Shi Liao. Shangai: Shanghai Remin Press, 1981. v. 1.

36 Declaration of National Students' Federation, June 1925, see THE SECOND HISTORICAL ARCHIVES OF CHINA. Wu $S a$ Yundong He Sheng Gang Bagong. Nanjing: Jiangsu Guji Press, 1985.

37 SHANGHAI ACADEMY OF SOCIAL SCIENCES I OF H. Wu Sa Yundong Shi Liao. Shangai: Shanghai Remin Press, 1981. v. 1.
}

The shooting down of the protestors in Shanghai and Qingdao soon angered workers and students in other cities. It is documented that at least 135 strikes nationwide were directly caused by the May 30 Incident to support Shanghai..$^{38}$ As anti-British and anti-Japanese sentiment intensified and tended to be more militant, more violent clashes took place. On June $11^{\text {th }}$, during a demonstration in Hankou, protesting workers engaged in a fight with the British police in the concession to prevent the police from arresting the students. The British marines opened fire on the protestors, resulting in eight deaths and eleven injuries. ${ }^{39}$ The resentment against British imperialism further escalated, and workers in Guangzhou and Hong Kong soon followed suite to support the workers in Shanghai and Hankou.

In Hong Kong and Shamian (the foreign concession in Guangzhou), a general strike outbroke on June $19^{\text {th }}$. Seamen, printers, and workers for the public transport struck first. Workers in foreign trade, cargo and coalmine and other unions followed suite, and finally mechanics and dock workers stopped work. Within 15 days, more than 250,000 workers were on strike. ${ }^{40}$ An important spur for the general strike was the Shaji Massacre on June $23^{\text {rd }}$. On that day, about 100,000 workers, peasants, military cadets, students and shopkeepers in Guangzhou took part in a demonstration, ${ }^{41}$ holding flags and banners written "Down with Imperialism", "Abolishing the Consular Jurisdiction", "Abolishing All Unequal Treaties", and "Supporting Victims of the May 30 Massacre in Shanghai". ${ }^{42}$ When they paraded along Shaji, the river bank opposite Shamian, the British and French troops opened fire from Shamian on the crowd. Fifty-two protestors died and more than 170 injured. ${ }^{43}$

The killing on June $23^{\text {rd }}$ further intensified the strike. A Strike Committee was formed by the end of the month by the All-China Federation of Trade Unions and decided to launch a massive boycott of trade

\footnotetext{
38 CHEN, T. The Labour Movement in China. International Labour Review, v. 15, n. 339, 1927; CHEN, T. Analysis of Strikes in China, from 1918 to 1926. London: Nabu Press, 2010.

39 THE SECOND HISTORICAL ARCHIVES OF CHINA. $W u$ Sa Yundong He Sheng Gang Bagong. Nanjing: Jiangsu Guji Press, 1985.

40 GUANGDONGSHENG et al. (ed.). Sheng Gang Da Bagong Ziliao. Guangzhou: Guangdong Remin Press, 1980.

41 GUANGDONGSHENG et al. (ed.). Sheng Gang Da Bagong Ziliao. Guangzhou: Guangdong Remin Press, 1980..

42 GUANGDONGSHENG et al. (ed.). Sheng Gang Da Bagong Ziliao. Guangzhou: Guangdong Remin Press, 1980.

43 ISAACS, H. The Tragedy of the Chinese Revolution. Chicago: Haymarket Books, 2009.
} 
against the British in Guangzhou. ${ }^{44}$ Measures were taken, including blocking shipment and importation of the British goods and refusing the British currency. The workers leaving en masse from Hong Kong were mainly seamen, dock workers, factory workers, workers for public transport and public utilities, and coolies. Their strike effectively cut off the food supply to the Hong Kong Island and the communication between the Hong Kong Island and the Kowloon district. Public infrastructure, such as sewage, was broken and left unrepaired. Garbage was dumped on the street and uncollected. Hong Kong (literally, the "fragrant port") became a "stinking port". ${ }^{45}$ As the strike and boycott continued throughout the months of July and August, further measures to isolate the island were taken by the Strike Committee. No goods coming from Hong Kong and Macao could dock in Guangzhou; no British ships and ships bypassing Hong Kong and Macao could load at any port in Guangdong. ${ }^{46}$ Hong Kong became a "dead port". For more than a year, all attempts at negotiation failed. The boycott caused an unprecedented economic loss to Hong Kong. Trade from Guangzhou to ports overseas was largely bogged down in July and August. It was documented that over the first eight months of the general Guangdong - Hong Kong boycott, shipments in Guangzhou, Shantou and Hong Kong had reduced to $20 \%{ }^{47}$ About 25,000 tons of goods arrived in Guangzhou through Hong Kong in the first half of 1925, and only 505 tons of goods went through this route in the second half of the year, most of which had already arrived in Shamian by the time of the boycott. ${ }^{48}$

\section{3 "Take It Now!": the taking down of the British concessions in Hankou and Jiujiang}

The anti-imperialist sentiment after the killing of the protestors on May $30^{\text {th }}$ in Shanghai and June $23^{\text {rd }}$ at

\footnotetext{
44 HORROCKS, R. J. The Guangzhou-Hongkong Strike, 1925-1926: Hongkong workers in an anti-imperialist movement. 1994. Available in: https://core.ac.uk/download/pdf/1145945.pdf Accessed on: 21 Sept. 2020.

45 ISAACS, H. The Tragedy of the Chinese Revolution. Chicago: Haymarket Books, 2009.

46 KUO, H-Y. Networks beyond empires: chinese business and nationalism in the Hong Kong-Singapore Corridor, 1914-1941. Leiden: BRILL, 2014.

47 GUANGDONGSHENG et al. (ed.). Sheng Gang Da Bagong Ziliao. Guangzhou: Guangdong Remin Press, 1980.

48 GUANGDONGSHENG et al. (ed.). Sheng Gang Da Bagong Ziliao. Guangzhou: Guangdong Remin Press, 1980.
}

Shaji continued to grow throughout the year of 1926. More than 500 strikes and mass demonstrations were held in $1926 .^{49}$ From these mass movements emerged not just economic demands (e.g., wage increases and improving working conditions). Economic demands were transformed into explicitly political ones concerning the unequal treaties and extraterritoriality. In such transformation from the socioeconomical to the political in this period of the anti-imperialist movements, what is particularly interesting is in Hankou and Jiujiang in the early January of 1927. In both cities, protesting workers and coolies spontaneously took over the British concessions. In the most general strikes and boycotts of the same period, the masses resisted against the imperialist rule and extraterritoriality often by directly targeting foreign factories and capitalists. While the abolition of concessions was indeed intended, this demand seemed to follow those more immediate ones about the improvement of socioeconomic conditions of the people. However, in Hankou and Jiujiang, foreign concessions, the exceptional spaces of law and order which were both the symbol and the (physical) source of the oppression and exploitation of Chinese people, became the direct object of the anti-imperialist struggles.

The seizure of the British concession in Hankou started with an anti-imperialist protest on the afternoon of January $3^{\text {rd }}, 1927$, outside the boundaries of the British concession. Barricades separated the agitated crowds and the bayonets-holding British marines. The angry protestors listened to lectures delivered by the impassionate students, shouted slogans of anti-British imperialism, waved poles and threw stones. As the anger was being aroused, a clash happened between the crowd and the British machines. ${ }^{50}$ There were different accounts about the casualties of the clash. The Chinese-language sources documented that one death and 30 injuries. ${ }^{51}$ Whether this number was correct or not, it was obvious that a small sparkle of violence would soon escalate nationwide. The provincial authority of the Nationalist

\footnotetext{
49 CHEN, T. Analysis of Strikes in China, from 1918 to 1926. London: Nabu Press, 2010.

50 CHAPMAN, H. O. The Chinese Revolution 1926-27: a record of the period under communist control as seen from the nationalist capital, Hankow. Edimburgo: Constable \& CO LTD, 1928.

51 XINHUA NEWS AGENCY. Shoubui Hankou, Jiujiang Yingzujie de Douzheng People's Daily. Beijing, 14 April 2007. Whereas according to Wilbur, five Chinese and three marines were injured, and no shots were fired. WILBUR, C. M. The Nationalist Revolution in China, 19231928. Cambridge: Cambridge University Press, 1985.
} 
Government, which had just moved from Guangzhou and established in Wuhan, immediately tried to forestall a bloody conflict by pledging to the British that they would take control over the crowds and demanding the British to withdraw the marines. ${ }^{52}$ The British authority of the concession, learning from what had followed the May $30^{\text {th }}$ and June $23^{\text {rd }}$, withdrew their forces and left the Chinese police to maintain order. The protestors also dispersed in the evening. However, in the afternoon of January $4^{\text {th }}$, protestors gathered again outside the British bund. Finding that the barricades were now open and policed by the Chinse, the crowds shouted, "Take it now!", removed the sandbags and barbed wires and rushed into the concession. ${ }^{53}$ The police station of the concession was attacked by stones. The municipal council of the concession decided to hand the station over to the Nationalist authorities; the Nationalist Government soon took it over and set up a commission to administer the concession. ${ }^{54}$

The British concession at Jiujiang was handed over to China in a similar fashion two days later. There, workers had already been on general strike in the closing months of 1926, demanding wage increases and paid holidays. The news about the clash in Hankou on January $3^{\text {rd }}$ infuriated the workers in Jiujiang. A mass demonstration was soon organized to support protestors in Hankou. On the afternoon of January $6^{\text {th }}$, protesting dockers, shouting "Down with the British Imperialists", rushed into the British concession and removed the barricades around the boundaries. The British authority barely resisted and agreed to let the Nationalist Government maintain order. ${ }^{55}$ On the next day, a Nationalist army entered and took over the concession.

While the KMT and the CPC had been mobilizing the masses and organizing strikes and boycotts, the mass actions of attacking the British concessions in Hankou and Jiujiang were largely spontaneous and without leadership. ${ }^{56}$ It was the first time in the mo-

\footnotetext{
52 WILBUR, C. M. The Nationalist Revolution in China, 1923-1928. Cambridge: Cambridge University Press, 1985.

53 ISAACS, H. The Tragedy of the Chinese Revolution. Chicago: Haymarket Books, 2009.

54 WILBUR, C. M. The Nationalist Revolution in China, 1923-1928. Cambridge: Cambridge University Press, 1985.

55 WILBUR, C. M. The Nationalist Revolution in China, 1923-1928. Cambridge: Cambridge University Press, 1985.; ISAACS, H. The Tragedy of the Chinese Revolution. Chicago: Haymarket Books, 2009.

56 ISAACS, H. The Tragedy of the Chinese Revolution. Chicago: Haymarket Books, 2009.
}

dern history of China, and indeed, the only time that foreign concessions were recovered by mass action in such an unexpected way. We can imagine the reactions of the frightened foreigners living in those privileged ghettoes, finding themselves, all of a sudden, surrounded by the angry Chinese. Stories about the looting and pillages by the "mobs" got told and retold all the way to the Shanghai International Settlement. Eyewitness accounts contradictory to those stories could also be found. ${ }^{57}$ Whatever the actual situation was, the mass actions in Hankou and Jiujiang were sufficiently alarming for the foreign powers in China. The British representtives in China and the Nationalist Government soon started negotiating the formal transfer of power in the two concessions. And by January $29^{\text {th }}$, Special Chinese Administrations were established in the two cities and former British municipal councils were dissolved.

\section{A brief Laclauan analysis of the populist characteristics of the Chinese anti-imperialist movements}

The four cases - the May 30 Incident in Shanghai, the general Guangzhou - Hong Kong strike and boycott, and the spontaneous attacks against the British concessions in Hankou and Jiujiang - exemplified the mass anti-imperialist movements in China in the mid 1920s. With the diligent anti-imperialist propaganda of the CPC and the KMT and the expansion of the workers' organisations throughout the whole country, the strikes and demonstrations were often participated

Chapman described the attack in Hankou against the British concession, "there were some instances of insolence and threats toward foreigners; but no personal violence was done and no houses entered." CHAPMAN, H. O. The Chinese Revolution 1926-27: a record of the period under communist control as seen from the nationalist capital, Hankow. Edimburgo: Constable \& CO LTD, 1928. Regarding the degree of mob violence in Jiujiang, Ransome observed that "very little furniture was broken and no windows, not even a very ugly ostentatious hanging lamp... A Chinese company officer... on meeting a soldier with any loot, took it. from him and solemnly handed it to the Englishmen, who, as the loot was usually a scrap of curtain or other useless junk, dumped it in the gutter... It is curious to observe that at 6 p.m. of that day a party of fifteen, two men and the rest women, who had come down...from Kuling, came through the Chinese streets into the Concession and down to the ships without molestation." RANSOME, A. The chinese purzle. Australian: Allen \& Unwin, Ltd, 1927. Available in: https://mcgill.worldcat.org/title/ chinese-puzzle/oclc/2754703\&referer=brief_results Accessed on: 5 Mar. 2020. 
by tens of thousands of people. However, it may still be too intuitive to claim these movements as populist. Such a claim may also easily fall into the tendency of conflating populism with xenophobic nationalism, which can often be found in the studies and commentaries of contemporary populism. ${ }^{58}$ Here, I draw on Ernesto Laclau's theory of populism to analyse and stress the populist characteristics of these movements. To be sure, choosing Laclau's theory does not presuppose that his theory and his approach to populism are universally accepted. The very term of populism indeed remains largely contested in the literature about populism. ${ }^{59}$ The reason of choosing Laclau's theory is due to its emphasis on populism as a political logic, ${ }^{60}$ as "a way of constructing the political" 61 " a way of doing politics" $"$. This approach, detaching populism with specific political programs and ideological contents, allows for a closer look at the formation, the structuring and the evolution of the movements which we may intuitively label as populist. It enables an understanding of, not just what claims and demands are made in those movements, but also how those claims and demands are made.

According to Laclau, populism cannot be properly understood by examining any particular sociological phenomenon. Populism, claims Laclau, "has no referential unity because it is ascribed not to a delimitable phenomenon but to a social logic whose effects cut across many phenomena." ${ }^{\text {63 }}$ Laclau approaches populism as a discursive strategy of constructing a political frontier that separates the society into "the people" and "the enemy" and calls for "the people" to unite and resist against "the enemy". ${ }^{64}$ Arato summarises these six elements of the Laclauan populism: First, the appeal to "the people" and "popular sovereignty" which work as empty signifiers, uniting heterogeneous demands and grievances; second, the claim that a part of society can

58 ALSTON, P. The Populist Challenge to Human Rights. Journal of Human Rights Practice, v. 9, n. 1, p. 1-15, fev. 2017.; POSNER, E. A. Liberal Internationalism and the Populist Backlash. Public Law and Legal Theory Working Papers, v. 66, 2017.

59 MUDDE, C.; KALTWASSER, C. R. Populism: a very short introduction. Oxford: Oxford University Press, 2017.

60 LACLAU, E. On Populist Reason. Rio de Janeiro: Verso, 2005.

61 LACLAU, E. On Populist Reason. Rio de Janeiro: Verso, 2005.

62 MOUFFE, C. For a Left Populism. Rio de Janeiro: Verso Books, 2018.

63 LACLAU, E. On Populist Reason. Rio de Janeiro: Verso, 2005.

64 LACLAU, E. On Populist Reason. Rio de Janeiro: Verso, 2005.; MOUFFE, C. For a Left Populism. Rio de Janeiro: Verso Books, 2018."plainCitation":'Laclau (n 60 stand for and represent the whole; third, the construction of a political frontier of antagonism; fourth, the unification through strong identification with a leader, or a unified leadership group; fifth, the use of rhetoric and affective argumentation and justification rather than rational arguments; sixth, the insistence on a strong notion of politics as opposed to mere "ordinary" politics or policy. ${ }^{65}$

With these elements in mind, I argue that the populist character of the mass movements in 1920s China was not only attributed to their strong tone of nationalism and anti-imperialism, which created a prima facie line of demarcation and antagonism. Race and nationality were important, but certainly not the only criteria that divided the society between the "underdogs" and the elitist enemies. The construction of "the people" and the unification of different social strata to form the political frontier were not self-evident either. Tensions deriving from the different interests and demands of specific social sectors and groups had to be straightened out in order to form a political coalition and a populist subject, "the people". ${ }^{66}$ The general strikes and boycotts in Shanghai, Guangzhou and Hong Kong illustrated vividly a strong political coalition comprised of very different social classes and sectors. Each class - factory workers, peasants, students, shopkeepers, as well as the Chinese nationalist bourgeoisies - and each faction within the class of workers had their specific and particular demands. ${ }^{67}$ Under the general banner of anti-imperialism, these demands were reframed to make them relatively compatible with each other, even though certain particular interests had to be compromised or sacrificed. ${ }^{68}$ The construction of a populist subject was, hence, predicated on the internal contradiction between

65 ARATO, A. How We Got Here? Transition Failures, Their Causes and the Populist Interest in the Constitution. Philosophy \& Social Criticism, v. 45, n. 9-10, p. 1106-1115, 2019.

${ }_{66}$ LACLAU, E. On Populist Reason. Rio de Janeiro: Verso, 2005.

${ }_{67} \mathrm{MAO}, \mathrm{Z}$. Analysis of the Classes in Chinese Society. China: Foreign Languages Press, 1956. Available in: http://collections.mun.ca/ PDFs/radical/AnalysisoftheClassesinChineseSociety.pdf Accessed on: 5 Mar. 2020.

68 For example, in the Guangzhou- Hong Kong strike, Chinese merchants and peasants suffered a great deal from the blockage of trade and shipment. The strike and boycott also caused extreme difficulties on citizens lived in Guangdong who were dependent on the imported rice and western medicine. HORROCKS, R. J. The Guangzhou-Hongkong Strike, 1925-1926: Hongkong workers in an anti-imperialist movement. 1994. Available in: https://core.ac.uk/ download/pdf/1145945.pdf Accessed on: 21 Sept. 2020. 
what Laclau calls the equivalence and difference. ${ }^{69}$ As the construction of "the people" being constantly contested, so was the political alliance that unified a large spectrum of social sectors. This is demonstrated by several historical studies which find that, counter the narrative about the voluntary self-organization of the workers, violence and intimidation were used by the unionists and pickets to force the reluctant workers to go on strikes. ${ }^{70}$

The identification of the enemy was similarly blurry and fluctuating, although "the foreign imperialists" seemed to have more concrete social referents. Apart from the foreign capitalists, foreign companies, foreign armed forces, and the foreign administration under extraterritoriality, the Chinese who had close ties with the British and the Japanese were also excluded from "the people". The Beijing Government and its officials who had the support of the foreign powers and largely accepted the Versailles-Washington system were seen as traitors, despite the diplomatic efforts made by the Beijing Government. In addition, during the Guangzhou - Hong Kong boycott, which caused tremendous economic loss to the Chinese merchants in Guangzhou, those who traded with the British were condemned by the CPC as the "running dogs" of the imperialists. ${ }^{71}$ The antagonistic division of the society into two camps and the intrinsic ambiguity of the division can be seen from Mao Zedong's Analysis of the Classes in Chinese Society. Reflecting on the recent mass movements, Mao wrote in March 1926 about distinguishing the real friends from the real enemies and uniting the former to attack the latter:

[A]ll those in league with imperialism - the warlords, the bureaucrats, the compradors, the big landlords, and the reactionary section of the intelligentsia dependent to them - are our enemies. The industrial proletariat is the leading force in our revolution. All sections of the semi-proletariat and the petty bourgeoisie are our closest friends. As to the vacillating middle class, its right wing may become our enemy and its left wing may become our friend, but we must be constantly on our guard towards the latter and not allow it to create confusion in our front. ${ }^{72}$

\footnotetext{
LACLAU, E. On Populist Reason. Rio de Janeiro: Verso, 2005.

70 CHAPMAN, H. O. The Chinese Revolution 1926-27: a record of the period under communist control as seen from the nationalist capital, Hankow. Edimburgo: Constable \& CO LTD, 1928.

${ }^{71}$ HORROCKS, R. J. The Guangzhou-Hongkong Strike, 1925-1926: Hongkong workers in an anti-imperialist movement. 1994. Available in: https://core.ac.uk/download/pdf/1145945.pdf Accessed on: 21 Sept. 2020.

${ }^{72} \mathrm{MAO}, \mathrm{Z}$. Analysis of the Classes in Chinese Society. China: Foreign
}

So, empirical referents for the terms of "the people" and "the foreign imperialists" can be relatively easily identified at the extremes of the broad spectrum of social strata in the Chinese society. However, between the two extremes of the spectrum, "the people" and "the foreign imperialists" were used more like the Laclauan "empty signifier", the "name", through which different social sectors and groups, with ambiguous political standings and heterogeneous interests, were identified and represented. ${ }^{73}$ The intrinsic ambiguity of the terms and the internal tension of the political frontier served like a double-edged sword: the masses of the Chinese society, regardless of their particular backgrounds, soon found a common identity and representation, i.e., the nationalist subject who resisted against the rule of foreign imperialism; nevertheless, not all chains in the coalition were equally strong and determined, which undermined the political frontier. Indeed, by the mid 1927, the anti-imperialist frontier founded on the KMT-CPC coalition broke down, as "the desire of the "poor to become "less poor" clashed with the ambition of the "less poor" to become richer." ${ }^{74}$

In the construction of the political frontier through the operation of empty signifiers, rational arguments gave way to rhetoric, affective and performative ones. Impassionate students giving anti-imperialist addresses in the mass demonstrations were described by the British "pose like martyrs" and "behave like mobs". ${ }^{75}$ In numerous petitions and declarations, extremely agitative words can be found, depicting the massacres in Shanghai, Hankou and Guangzhou and stressing the precarity of the life and freedom of the Chinese people under the threat of imperialist violence. In addition, through those sensational and provocative languages, the mass movements made bold political demands and objectives, targeting the historical sources of the mass frustration, i.e., the unequal treaties and extraterritoriality (which were called the national humiliation). Not only were reconciliations and compromises rejected, legalist solutions were denied as well. As the CPC declared on June 5, 1925:

Languages Press, 1956. Available in: http://collections.mun.ca/ PDFs/radical/AnalysisoftheClassesinChineseSociety.pdf Accessed on: 5 Mar. 2020.

73 LACLAU, E. On Populist Reason. Rio de Janeiro: Verso, 2005.

74 ISAACS, H. The Tragedy of the Chinese Revolution. Chicago: Haymarket Books, 2009.

75 KUO, H-Y. Networks beyond empires: chinese business and nationalism in the Hong Kong-Singapore Corridor, 1914-1941. Leiden: BRILL, 2014. 
the [May 30] incident in Shanghai is not accidental. Its nature is not legal, but completely political... The objective of the resistance movement in Shanghai and nationwide against the British and Japanese imperialism shall not stop at punishing the perpetrators, compensating the victims and apologies. The solution is not in law but in politics. The prime objective should be the abolition of all unequal treaties and all privileges of the imperialists in China ... This resistance movement in Shanghai and nationwide triggered by the massacre will be a long-term national struggle. Its outcome will not depend on whether the British and Japanese imperialists accept the conditions about punishment, compensation and apologies. ${ }^{76}$

In brief, the populist character of these movements described previously was not simply due to its large number of participants and its confrontational standing against the foreigners. Instead, the populist character was reflected by the imprecision and ambiguity in the construction of the people and the enemy, the call for radical political solutions, and the highly affective and sensational discourses that completely denounced the imperialist rule of the game. The intrinsic tension of the political frontier meant that sustaining the anti-imperialist movements was challenging and required continuous mobilization and reconstruction of the antagonistic line. Except the British concessions in Hankou and Jiujiang, many strikes and boycotts, although making determined political demands and objectives, eventually died down; the reward for the striking workers was largely limited to pay raises or compensations. ${ }^{77}$ However, the net effect of these movements was that the foreign powers, especially the United Kingdom, became extremely cautious and tried everything to avoid conflicts with the Chinese people, in order to protect its interests and the safety of its nationals in China.

\footnotetext{
76 SHANGHAI ACADEMY OF SOCIAL SCIENCES I OF H. Wu Sa Yundong Shi Liao. Shangai: Shanghai Remin Press, 1981. v. 1.

77 As documented by Chen Ta, among the 135 recorded strikes following the May 30 Incidents, there were one case of complete success, 35 cases of partial success, one case of failure and 98 cases not reporting. The right to organize trade unions was recognised in 17 cases, and in 16 cases, the workers received a subsidy for the strike period in addition to an improvement in working conditions. In 18 cases, the strikers obtained wage increases. CHEN, T. The Labour Movement in China. International Labour Review, v. 15, n. 339, 1927.
}

\section{Impacts on the process of treaty- revision and the abolishment of extraterritoriality}

\subsection{Direct impacts: the British December Memorandum and the Treaty Alteration Programme}

As mentioned in the introduction, after the Paris Peace Conference, the Beijing Government had started bilateral negotiations with each foreign power on the treaty revision and the abolition of extraterritoriality. Although making some important progress, ${ }^{78}$ the Beijing Government, who accepted the Versailles-Washington system but was unable to press the United Kingdom on the process of treaty revision, was criticized by the nationalists as traitorous. Drastically different from the policy of the Beijing government, the Nationalist regime in Guangzhou, while mobilizing anti-imperialist movements, propagated the "revolutionary diplomacy" "79 and declared all the unequal treaties were null. The May 30 Incident escalated the sentiment of anti-British imperialism to an unprecedented level. The general Guangzhou - Hong Kong strike and boycott further brought significant economic loss to the British trade and investment. Following the May 30 Incident and the Guangzhou - Hong Kong strike, the UK government had started to review its policy regarding China in order to defuse the crisis. A clear example of the changing attitude can be found in the discussion by Victor Wellesley, then Deputy Under Secretary for Foreign Affairs at the Foreign Office:

[The Nationalist Movement] is not a transient one.
It is a thing that has come to stay, to grow and
to be reckoned with. The two great aims of this
movement are: 1 . complete fiscal autonomy and 2 .
complete surrender of extraterritoriality... Nothing
short of complete surrender on both points will
give real satisfaction to the Chinese. The time is
now quite clearly passed when we could afford to
ignore such demands or browbeat the Chinese into
submission. We have consequently got to realize

78 During the First World War, China declared war on the AustroHungarian Empire and abolished German and Austro-Hungarian extraterritorial jurisdictions and concessions. After the Soviet revolution in 1917, the Beijing government terminated China's diplomatic relationship with the Russian Empire and abolished Russian extraterritorial jurisdiction and concessions on September 23, 1920. 79 HAN, X. Chinese Discourses on the Peasant, 1900-1949. New York: SUNY Press, 2012. 
that in the face of this growing determination to be rid of foreign shackles we cannot indefinitely maintain our Treaty rights and privileges and that they must sooner or later be surrendered unless we are prepared to use force which I think is generally admitted to be out of the question. ${ }^{80}$

In December 1926, the British government issued the Proposals to the Powers Concerning China, also known as the December Memorandum. In the Memorandum, the UK government reaffirmed the spirit of the Washington Conference and called upon all treaty powers at the Washington Conference to declare their readiness to negotiate on treaty revision with China, as soon as China had a government. In particular, the Proposal suggested that:

\begin{abstract}
[the treaty powers] should abandon the idea that the economic and political development of China can only be secured under foreign tutelage... [and] should expressly disdain any intention of forcing foreign control upon an unwilling China. While calling upon China to maintain that respect for the sanctity of treaties which is the primary obligation common to all civilized States, the Powers should recognise both the essential justice of China's claim for Treaty revision and the difficulty under present conditions of negotiating new treaties in place of the old, and they should therefore modify their traditional attitude of a rigid insistence on the strict letter of treaty rights. ${ }^{81}$
\end{abstract}

The Memorandum continued to call upon all the treaty powers to stop protesting on some minor matters, to consider China's reasonable proposals with sympathy even if the proposals were against strict interpretation of treaty rights, and to maintain harmonious relations with China "without waiting for or insisting on the prior establishment of a strong Central Government". ${ }^{82}$

The December Memorandum, in addition, urged

\footnotetext{
80 Wellesley, Situation in China, Foreign Office Minute, 12 August 1925, [F3860/2/10] (FO 371/10922) at 92-93. Another example of the changing attitudes can be found in Eric Teichman's remark in his Memorandum on the position of Foreigners in China today, with Special Reference to the Questions of Treaty Revision that "it is as useless for us to bury our heads like ostriches in the san and ignore these inevitable developments as it is for the Chinese to ask for the moon and suppose that China can leap at one bound from her old state to one of complete equality with the nations of the West. It is therefore necessary for all us us...to face the facts of the situation and be prepared in due course to adjust ourselves gradually to new conditions of trade and residence in China." August 6, 1925 [F 3678/2/10] (FO 371/10921) at 237.

81 WOODHEAD, H. G. W. (ed.). The China Year Book. China: Tientsin Press, 1928.

82 WOODHEAD, H. G. W. (ed.). The China Year Book. China: Tientsin Press, 1928.
}

the treaty powers to unconditionally and immediately authorize the Chinese authorities to levy surtaxes throughout China. ${ }^{83}$ This proposal was immediately agreed by the US, the Netherlands, Italy and Spain, but objected by Japan. ${ }^{84}$ Apart from the unconditional authorization of the levy of surtaxes, the Memorandum was more suggestive of the British attitude and intention, rather than planning any concrete measures to be taken to revise relevant treaties. Meanwhile, both the Beijing Government and the Nationalist Government were unhappy with the document, each claiming themselves as the only legitimate Chinese government and blaming the British for implicitly supporting the rival regime. The negotiations between the UK and China remained difficult. The memorandum did not produce any immediate progress for the negotiation with China and needed careful implementation by the British government and its representatives in China. Nevertheless, it set out the tone for the subsequent interactions with the Chinese authorities.

A few days after the publication of the British Proposals, large demonstrations in Hankou and Jiujiang led to the seizure of the British concessions by crowd actions. As mentioned earlier, the British authorities accepted the proposals by the Nationalist Government to withdraw their armed forces, so as to avoid a repetition of the May 30 and the June 23 incidents, and eventually placed the concessions under the administration of the Nationalist government. Compelled by the dangerous escalation of the events, the British government accepted the seizure of the British concessions as fait accompli. The events in Hankou and Jiujiang had pushed the British government to directly approach the Nationalist regime who had been advocating the policy of "revolutionary diplomacy", to deal with the formal handover of the concessions and to seek the assurance from the Nationalist Government that the Hankou and Jiujiang incidents would not happen again.

On January $27^{\text {th }}, 1927$, the British government proposed to the Nationalist Governments its Treaty Alteration Programme to appease the nationalists. The proposal expressed the intentions, inter alia, to recognize Chinese law as applicable and modern Chinese law

\footnotetext{
83 WOODHEAD, H. G. W. (ed.). The China Year Book. China: Tientsin Press, 1928.

84 TANG, Q. Treaty revision campaign of the Beijing Government, 1912 1928: out of the shadow of the 'Abrogation of Unequal Treaties'. Beijing: Social Sciences Academic Press, 2010.
} 
courts as competent for cases involving British subjects, to recognize the Chinese taxation as applicable to the British subjects in China, and to negotiate on the modification of municipal administration of British concessions in China and on the transfer of police control of British concessions to the Chinese authorities. ${ }^{85}$

On the same day of the issuance of the Treaty Alteration Programme, the British representative Owen O'Malley told Eugene Chen, representative of the $\mathrm{Na}$ tionalist government in Wuhan, that the British government was willing to concede as long as the Nationalist Government assured that any modification about the status of British concessions and the Shanghai International Settlement would be made only by negotiation. ${ }^{86}$ Chen responded by declaring that "the liberation of China from the yoke of foreign imperialism need not necessarily involve any armed conflict between Chinese Nationalism and the foreign Powers"87, and that the Nationalist Government was ready to negotiate separately with the treaty powers for a settlement of treaty and other related questions on a basis of "economic equality and mutual respect for each other's political and territorial sovereignty". ${ }^{88}$ Furthermore, the Nationalist Government considered the proposals of the Treaty Alteration Programme unsatisfactory and inadequate but was willing to consider them as a basis of a comprehensive and reasoned settlement of the existing differences between the Nationalist Government and the United Kingdom. ${ }^{89}$

In short, the populist movements of anti-imperialism compelled the United Kingdom, the most important foreign power in China, to significantly change its attitude toward China and concede to some of the nationalist demands regarding extraterritoriality. While a complete and immediate abolition of extraterritoriality was still impossible to attain, the vast energies generated by the populist movements both indicated and facilitated the gradual crumbling of the imperial rule of the international relations. This slow but fundamental

85 WOODHEAD, H. G. W. (ed.). The China Year Book. China: Tientsin Press, 1928.

86 WOODHEAD, H. G. W. (ed.). The China Year Book. China: Tientsin Press, 1928.

87 WOODHEAD, H. G. W. (ed.). The China Year Book. China: Tientsin Press, 1928.

88 WOODHEAD, H. G. W. (ed.). The China Year Book. China: Tientsin Press, 1928.

89 WOODHEAD, H. G. W. (ed.). The China Year Book. China: Tientsin Press, 1928. transformation of the international order was seen by UK's explicit acknowledgement of the essential justice of China's nationalist demands, the clear exclusion of the possibility to use force to maintain its imperial rule in China, its willingness to go beyond the strict and legalist approach to treaty interpretation, and its endorsement of the spirit of the Washington Conference.

\subsection{Indirect impacts: providing leverage for the Beijing government}

As the anti-imperialist movements in the southern part of China went in full swing, the Beijing Government was also actively seeking diplomatic breakthroughs to recover China's sovereignty and change the status of extraterritoriality. Although the populist movements, mobilized by the Nationalist Government and the CPC, criticized the Beijing Government as traitorous and representative of the foreign imperialism, the movements provided the Beijing Government with some interesting leverage in its negotiation with the foreign powers in the process of treaty revision.

The December Memorandum issued by the British government at the end of 1926 to appease the nationalist and anti-British sentiments in China significantly eased the diplomacy of the Beijing Government with other treaty powers. An interesting example here is Belgium. The publication of the December Memorandum had an unintended consequence for the Belgian concession in Tianjin. Belgium was the weakest among all the foreign powers in China. While having made huge investments, Belgium did not have troops in Chinese territories and hence, relied on the solidarity of the foreign powers to protect its interest in China. The Beijing Government approached Belgium in April 1926 on the revision of the treaty of 1865 . Invoking the doctrine of rebus sic stantibus, ${ }^{90}$ it expressed the intention to terminate the same treaty by October $27^{\text {th }}, 1926$ and to replace it with new agreements. ${ }^{91}$ Unable to agree on the content of a modus vivendi with Belgium, the Beijing Government unilaterally terminated the treaty on November

\footnotetext{
90 TSENG, Y-H. The termination of unequal treaties in international law: studies in comparative jurisprudence and Conventional Law of Nations. Pequin: The Commercial Press, Ltd, 1931. Available in: https://heinonline.org/HOL/P?h=hein.hoil/trmunql0001\&i=75 Accessed on: 3 Mar. 2020.

91 KOO, V. K. W. Wellington Koo's Foreign Policy: some selected documents. Shanghai: Wunsz King ed, Kelly ad Walsh, 1931.
} 
$6^{\text {th }}, 1926 .{ }^{92}$ Belgium protested against the unilateral termination of the treaty and submitted the dispute to the Permanent Court of International Justice. However, by late December 1926, the British December Memorandum, which called upon the treaty powers to maintain harmonious relationships with China and to consider China's reasonable proposals with sympathy, signposted a significant change of the British policy toward China. The timing of its issuance dramatically changed the power dynamics between China and Belgium. Following the December Memorandum, Belgium agreed to resume negotiation with the Beijing Government and to enter into new agreements on the basis of equality and respecting each other's territorial sovereignty. On $17 \mathrm{Ja}-$ nuary 1927, Belgium declared its abandonment of the concession in Tianjin and returned it to China. ${ }^{93}$

The incidents in Hankou and Jiujiang in early January of 1927 were also turned into an opportunity for the Beijing Government to press the British on the negotiation of treaty revision. The Beijing Government was unhappy that the Nationalist Government, whose had propagated the "revolutionary diplomacy", refused to recognize the treaties and had resorted to violence, was able to make such an important progress of restoring two British concessions in the south. The Beijing Government believed that as it recognized the treaties and sought peaceful negotiations with the UK, it deserved more favourable treatment than what the Nationalist regime achieved, and that the UK should concede and agree on the terms made by the Beijing Government. The Beijing Government claimed that, otherwise, it would no longer help the UK supress the anti-British movements in the north and that it would even consider restoring the British concession in Tianjin in a fashion similar to those of Hankou and Jiujiang. ${ }^{94}$

To prevent the situation in the north from becoming as thorny as that in the South, the British government made the same proposals of the Treaty Alteration Programme to the Beijing Government on January $28^{\text {th }}$. The Beijing Government did not want to be restrained by the British proposals in the formal negotiations on

\footnotetext{
92 KOO, V. K. W. Wellington Koo's Foreign Policy: some selected documents. Shanghai: Wunsz King ed, Kelly ad Walsh, 1931.

93 QUIGLEY, H. S. Foreign concessions in chinese hands. 1928. Available in: https://www.foreignaffairs.com/articles/china/1928-10-01/ foreign-concessions-chinese-hands Accessed on: 5 Mar. 2020.

94 TANG, Q. Treaty revision campaign of the Beijing Government, 1912 1928: out of the shadow of the 'Abrogation of Unequal Treaties'. Beijing: Social Sciences Academic Press, 2010.
}

the treaty revision, only accepted the proposals as the basis for the informal negotiation about the unilateral abandonment by the British of its rights and interests in China, rather than the basis for the treaty revision. ${ }^{95}$ In the next few months, the two parties used the proposals as a starting point for the negotiation on the status of the British concession in Tianjin and signed a preliminary proposal to put the concession under the joint control of the Chinese, the British and the American on April $22^{\text {nd }}, 1927 .^{96}$

The Beijing Government survived for another year. During this time, the internal factional conflicts and the war with the National Government had largely limited further diplomatic progress on the treaty revision. However, at least, during the high tide of the nationalist and anti-imperialist movements in the years of 1926 and 1927, the Beijing Government had taken advantage of them to advance its demands in its interactions with the foreign powers, even though it was also helping the foreign powers to quiet down the anti-imperialist sentiments and suppressing the communist movements in the north. By reaping the fruits of the anti-imperialist movements, the Beijing Government was able to put the British government in a difficult situation, i.e., that the UK had to be, at least, as generous to the Beijing Government as it had been to the Nationalist Government. As Miles Lampson, then British Minister to China, remarked, "We must not at present take sides (between the north and the south) if we can help it or be rushed by either of them... Our treaty modification programme was made simultaneously to China as a whole. The North are in process of accepting it, the South so far are not. But that is no justification for holding up the offer to the North nor is it in any case now possible to do so..."

\subsection{Aftermath: the fragility of the populist movements}

The takeover of the British concessions in Hankou and Jiujiang had one additional serious consequence

TANG, Q. Treaty revision campaign of the Beijing Government, 19121928: out of the shadow of the 'Abrogation of Unequal Treaties'. Beijing: Social Sciences Academic Press, 2010.

96 TANG, Q. Treaty revision campaign of the Beijing Government, 1912 1928: out of the shadow of the 'Abrogation of Unequal Treaties'. Beijing: Social Sciences Academic Press, 2010.

97 Lampson to Teichman, 14 March 1927, FO371/12403 [F2370/2/10]. 
for the system of extraterritoriality. The takeover by mass action, as well as the stories of looting and harassment against the foreigners, soon alerted the foreign authorities in the Shanghai International Settlement. The British Consul and the naval commander-in-chef estimated that Shanghai would be the next target of the military campaign of the Nationalist against the Beijing Government in the north and requested the military reinforcement of Shanghai. ${ }^{98}$ While the negotiation between O'Malley and Chen was taking place in Hankou in January, the British government sent an expeditionary force of English and Indian infantry to Shanghai, including cavalry, tanks, aeroplanes, artillery and hospital units, and another force of a few thousands to Hong Kong in reserve. The total number of the military dispatch was more than 20,000 men. ${ }^{99}$ The Japanese, American and French governments also sent troops to reinforce Shanghai. ${ }^{100}$ The move by the British was protested by Chen who almost pulled out from the deal with O'Malley in Hankou. ${ }^{101}$ A compromise was reached eventually: Chen issued a formal statement to ensure that the Nationalist Government would not use force to effect the changes of the status of the concessions; Austen Chamberlain, then British foreign secretary, also assured that the British forces would retreat to Hong Kong, if the Hankou agreement was signed and no further emergence happened. ${ }^{102}$

However, the situation in Shanghai remained intense. The anti-imperialist movements had not gone down. Instead, inspired by the success in Hankou and Jiujiang, workers' organizations and communists in Shanghai continued to rally the movements. Furthermore, from those movements emerged some sort of rule by the workers and communists in Shanghai. ${ }^{103}$ The British, as

\footnotetext{
98 WILBUR, C. M. The Nationalist Revolution in China, 1923-1928. Cambridge: Cambridge University Press, 1985.

99 CHAPMAN, H. O. The Chinese Revolution 1926-27: a record of the period under communist control as seen from the nationalist capital, Hankow. Edimburgo: Constable \& CO LTD, 1928.

100 CHAPMAN, H. O. The Chinese Revolution 1926-27: a record of the period under communist control as seen from the nationalist capital, Hankow. Edimburgo: Constable \& CO LTD, 1928.

101 WOODHEAD, H. G. W. (ed.). The China Year Book. China: Tientsin Press, 1928.

102 WOODHEAD, H. G. W. (ed.). The China Year Book. China: Tientsin Press, 1928.

103 According to Isaacs, the workers' pickets patrolled the city and had 2700 men and 1700 rifles. A provisional government, in the name of Shanghai's workers, was even set up under the Communist control which was ready to take over political power throughout the Shanghai area. ISAACS, H. The Tragedy of the Chinese Revolution.
}

well as other foreign powers in Shanghai, did and could not concede this time, as Shanghai hosted huge amount of foreign businesses and nationals. Armed forces kept being dispatched to Shanghai to guard the concessions and to protect the foreigners. The reinforcement of Shanghai by foreign military forces was seen by the nationalists as a dangerous provocation and an insult to China's sovereignty, hence irritating the anti-imperialist sentiments even more. ${ }^{104}$ On March $24^{\text {th }}, 1927$, a major attack on the foreigners happened in the Nationalist-controlled Nanjing by a Chinese troop of a rival military faction. As a result of the attack, the number of foreign troops garrisoning in Shanghai was soon increased to 30,000 , and 45 foreign warships anchored at the Huangpu River for immediate action. ${ }^{105}$ In addition, the UK, Japan, the US, France, and Italy demanded the Nationalist Government for satisfaction. The Nationalist Government replied with a proposal of setting up an international commission of inquiry to investigate the attack in Nanjing and meanwhile, made the counter-claim regarding the unequal treaties:

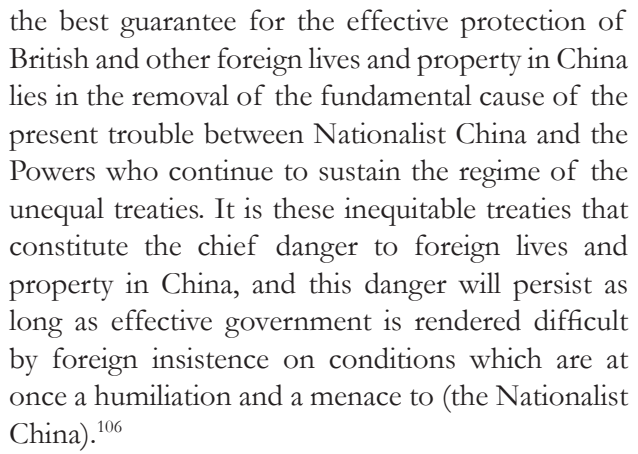

A deadlock, hence, arose from the escalating tensions: the growing and increasingly militant anti-imperialist movements, as well as other anti-foreignist military factions, alerted the foreign powers and compelled them to defend their interests in Shanghai, which provoked more indignation on the part of the Chinese who wanted the complete abrogation of the unequal treaties and extraterritoriality. Shanghai became one of the most difficult international issues from 1927 to early

Chicago: Haymarket Books, 2009.

104 CHAPMAN, H. O. The Chinese Revolution 1926-27: a record of the period under communist control as seen from the nationalist capital, Hankow. Edimburgo: Constable \& CO LTD, 1928.

105 ISAACS, H. The Tragedy of the Chinese Revolution. Chicago: Haymarket Books, 2009.

106 HC Deb 26 April 1927, vol 205, c665, at c667, Available in: https://api.parliament.uk/historic-hansard/commons/1927/apr/26/ nanking-outrages Accessed on: 3 Jul. 2020. 
1930s. ${ }^{107}$ The deadlock was, however, partly resolved in April 1927 when the KMT - CPC alliance was broken. The Nationalist Government had internally split and the right-wing part of the KMT led by General Jiang Jieshi established a government in Nanjing and started a nationwide reign of terror. The communists were purged from the KMT, and numerous labour and communist organizations were disbanded and largely destroyed. In Shanghai, foreign troops also participated in the raids against the workers with the permission of the Nanjing Government. As a result, the political frontier of anti-imperialism collapsed, and the mass movements died down. In June 1928, the Nanjing Government overthrew the Beijing Government and united the entire China. Departing from the early Nationalist policy of "revolutionary diplomacy", the Nanjing Government inherited the diplomatic policy and results of the Beijing Government and resumed the negotiations with the foreign powers on treaty revision.

\section{Conclusion}

The mass movements in the 1920s in China had unique international and domestic conditions. The rise of national consciousness at home coalesced with, and was strengthened by, the rise of Wilsonianism and Bolshevism internationally. Meanwhile, the First World War also significantly changed the structure of the domination by the Western powers in China, compelling them to readjust their positions to the new conditions in China. Populism, seen as a way of doing politics, featured in this period by forging the alliances of different social sectors and classes in China and uniting them around the same political cause of anti-imperialism. In the four events that I have discussed in Section 2, the "underdogs" - identified both by their race and classes - were primarily motivated by the grievances caused by their socioeconomic conditions. However, in building the political frontier of anti-imperialism, socioeconomic demands were transformed into highly political ones. The hardship in life that the Chinese people had to face

107 WANG, M. The publication and abandonment of the report of the hon: Richard Feetham in the context of changes in sino-british relations. Li Shi Yan Jiu, n. 83, 2012.; WANG, M. The publication and abandonment of the report of the hon: Richard Feetham in the context of changes in sino-british relations. Li Sbi Yan Jiu, n. 83,2012 every day was, then, connected with and even attributed to the domination and exploitation by the foreign powers in China. In this transformation from the socioeconomical to the political, the brutal reactions of the foreign powers in China to people's demands, as well as the reactions of the Chinese local authorities dependent on the foreign military support, in turn, stimulated and accelerated this transformation and provided a strong anti-imperialist lens to the perception and the framing of the frustrations and miseries that people experienced.

As the imperialist domination in China was not simply political and military, but also legal and legalised, the Chinese populism of the 1920s attacked the legal underpinnings and framework of the imperialist domination. The primary targets of this radical political frontier were the unequal treaties and the system of extraterritoriality, and the way of resisting against them was by neither formal political negotiations, nor international adjudications, although some side-effects on the legal and political processes indeed occurred. This rejection of the formal political and legal procedures was in sharp contrast with the policy and method of the Beijing Government. The Beijing Government, while unilaterally terminated a few treaties (e.g., the treaties with Germany, Austria and Belgium), never denounced the pre-existing treaties as null ab initio but invoked the Rebus Sic Stantibus doctrine to seek treaty revisions. The way of the populist resistance was something outside and profoundly subversive of the extant international legal system. From organized strikes and boycotts of trade to spontaneous mass actions, what was claimed and demanded was not a different viewpoint about international law but a completely different political and legal order. The masses were "asking for the moon", ${ }^{108}$ as it were. In such an irrational confrontation, violence was perhaps not only difficult to avoid but a precondition: pushing forward such claims itself (e.g., an outright rejection of the treaties and the system of extraterritoriality) constituted a violence against the existing legal order and logic. The violence caused by the irrationality of the confrontation was further augmented by the populist way of creating the confrontation and initiating political action, as populism always relies on imprecise and flexible terms and simplified dichotomies. In short,

108 Eric Teichman's remark in the Memorandum on the position of Foreigners in China today, with Special Reference to the Questions of Treaty Revision, $\mathrm{n}(62)$. 
the populist resistance against foreign imperialism in the 1920s in China was beyond the comprehension and appropriation of the existing international legal order. The populist movements further sought to radicalise that legal order into a new one.

From the claims made by those movements in the 1920 s, what is also interesting is that the claims did not quite give the impression of nostalgie de la boue, or an isolationism that aimed to disconnect China from the international political economy. In addition, as the anti-imperialist frontier also united the national bourgeoises, the nationalist attack on the imperialist economic domination in China had not yet turn into a full-fledged communist objective of dismantling global capitalism. Instead, in the populist claims, we can discern the hope that international trades and investments would sti11 flourish in a new legal and world order founded on the sovereign and racial equality. This hope was quite plainly reflected in the demands of the striking workers. They did not argue that foreigners should not build factories in China and should not hire them, and they did not argue that the Chinese workers should only work for the Chinese capitalists. Rather, what they resisted against was the impunity with which the foreign capitalists could abuse them, and what they demanded was their rights to be recognized and respected by their foreign employers. As for the abolition of the foreign concessions, the protestors did not demand the foreigners to leave, but that the Chinese residents who were also taxpayers in the concessions should at least have a say in the administration and government of the concessions as well. Hence, these demands suggested a world vision which was not really Manichean, but more ambiguous and more complicated. While this subtly non-Manichean feature of this world vision may lead to its cooption, this world vision did not accept easy reconciliation and surface adjustment - an immediate improvement of socioeconomic status and conditions was the direct cause of the mass movement but not the endgame. This radicality and the "irrationality" of the populist world vision contained the progressive potential of correcting the deep-seated injustice of the world political economy and international law, while avoiding the paradox of reinforcing the logic of "colonial compartmentalisation" ${ }^{\prime \prime 109}$.

FANON, F. The Wretched of the Earth. Chicago: Richard Philcox tr, Grove Press, 2004.
However, as the historical events turned out, the progressive potential of the populist movements was, at the same time, frail. The political frontier of anti-imperialism was full of internal conflicts and the populist energy could easily be captured by the right wing who would in turn kill the movements. As the movements died down in April 1927, the lesson about the progressive potential of populism to transform international law and to bring out a different world got largely buried. Fast forward almost a hundred years, the kind of populism that was seen in the national liberation and anticolonial movements attracts far less attention in the mainstream legal scholarship than those populist movements in established democracies. This article, I hope, would contribute to the rediscovery of the legacy of populism in the development of international law, not only just how populism poses a danger to international law but how populism directs international law to reconsider some of its fundamental questions, such as its legitimacy and the alternative and contesting imaginaries. In a time where we have seen many crises emerging while many voices remain unheard, it is of great importance to reclaim populism and re-enact its progressive potential, and it is even more urgent as some right-wing populists precisely appropriate anticolonial discourses. ${ }^{110}$

\section{References}

ALSTON, P. The Populist Challenge to Human Rights. Journal of Human Rights Practice, v. 9, n. 1, p. 1-15, fev. 2017.

ANGHIE, A. Imperialism, sovereignty and the making of international law. Cambridge: Cambridge University Press, 2007.

ARATO, A. How We Got Here? Transition Failures, Their Causes and the Populist Interest in the Constitution. Philosophy \& Social Criticism, v. 45, n. 9-10, p. 11061115, 2019.

BENTON, L. Made in empire: Finding the history of international law in imperial locations: introduction. Leiden Journal of International Law, v. 31, n. 3, p. 473-478, 2018.

$\overline{110}$ KOROLCZUK, E.; GRAFF, A. Gender as "Ebola from Brussels": the anticolonial frame and the rise of illiberal populism. Signs: Journal of Women in Culture and Society, v. 43, n. 797, 2018 
BUGARIC, B. Central Europe's descent into autocracy: a constitutional analysis of authoritarian populism. International Journal of Constitutional Law, v. 17, n. 2, p. 597-616, jul. 2019.

BUGARIC, B. The two faces of populism: between authoritarian and democratic populism. German Law Journal, v. 20, n. 3, p. 390-400, abr. 2019.

CHAPMAN, H. O. The Chinese Revolution 1926-27: a record of the period under communist control as seen from the nationalist capital, Hankow. Edimburgo: Constable \& CO LTD, 1928.

CHEN, T. Analysis of Strikes in China, from 1918 to 1926. London: Nabu Press, 2010.

CHEN, T. Labor Conditions in China. Monthly Labor Review, v. 19, n. 5, p. 36-49, nov. 1924.

CHEN, T. Labor Unrest in China. Monthly Labor Review, v. 13, n. 16, 1921.

CHEN, T. The Labor Situation in China. Monthly Labor Review, v. 11, n. 207, 1920.

CHEN, T. The Labour Movement in China. International Labour Review, v. 15, n. 339, 1927.

CHIMNI, B. S. Capitalism, imperialism, and international law in the twenty-first century. Oregon Review of International Law, v. 14, n. 17, 2012.

DE LA TORRE, C. Populism in Latin America. Oxford: Oxford University Press, 2017. Available in: https:// www.oxfordhandbooks.com/view/10.1093/oxfordhb/9780198803560.001.0001/oxfordhb9780198803560-e-8 Accessed on: 21 Feb. 2020.

DOYLE, O. et al. Populism: a health check for constitutional democracy? German Law Journal, v. 20, n. 401, 2019.

EATWELL, R.; GOODWIN, M. National populism: the revolt against liberal democracy. London: Penguin UK, 2018.

ESLAVA, L. et al. Bandung, global history, and international law: critical pasts and pending futures. Cambridge: Cambridge University Press, 2017.

FANON, F. The Wretched of the Earth. Chicago: Richard Philcox tr, Grove Press, 2004.
GILMAN, N. The new international economic order: a reintroduction. Humanity: An International Journal of Human Rights, Humanitarianism, and Development, v. 6, n. 1, 2015.

GUANGDONGSHENG, et al. (ed.). Sheng Gang Da Bagong Ziliao. Guangzhou: Guangdong Remin Press, 1980.

HAN, X. Chinese Discourses on the Peasant, 1900-1949. New York: SUNY Press, 2012.

HORROCKS, R. J. The Guangzhou-Hongkong Strike, 1925 1926: Hongkong workers in an anti-imperialist movement. 1994. Available in: https://core.ac.uk/download/pdf/1145945.pdf Accessed on: 21 Sept. 2020.

HOSTOVSKY BRANDES, T. International law in domestic courts in an era of populism. International Journal of Constitutional Law, v. 17, n. 576, 2019.

HOWSE, R. Epilogue: in defense of disruptive democracy: a critique of anti-populism. International Journal of Constitutional Law, v. 17, n. 641, 2019.

HUGHES, Charles E. et al. Conference on the Limitation of Armament. The American Journal of International Law, v. 16, n. 2, p. 159-233, apr. 1922.

ISAACS, H. The Tragedy of the Chinese Revolution. Chicago: Haymarket Books, 2009.

JOUANNET, E. The liberal-welfarist law of nations: a history of international law. Cambridge: Cambridge University Press, 2012.

KINGSBURY, B. Sovereignty and inequality. European Journal of International Law, v. 9, n. 599, 1998.

KOO, V. K. W. Wellington Koo's Foreign Policy: some selected documents. Shanghai: Wunsz King ed, Kelly ad Walsh, 1931.

KOROLCZUK, E.; GRAFF, A. Gender as "Ebola from Brussels": the anticolonial frame and the rise of illiberal populism. Signs: Journal of Women in Culture and Society, v. 43, n. 797, 2018.

KRIEGER, H. Populist Governments and International Law. European Journal of International Law, v. 30, n. 971, 2019.

KUO, H-Y. Networks beyond empires: chinese business and nationalism in the Hong Kong-Singapore Corridor, 1914-1941. Leiden: BRILL, 2014.

KUO, M-S. Against Instantaneous Democracy. International Journal of Constitutional Law, v. 17, n. 554, 2019. 
LACLAU, E. On Populist Reason. Rio de Janeiro: Verso, 2005.

LEE, E-H. Bei Fa Qianhou de Gemin Waijiao (1925-1931). Taiwan: Institute of Modern History, Academic Sinica, 1993.

MAO, Z. Analysis of the Classes in Chinese Society. China: Foreign Languages Press, 1956. Available in: http:/ / collections.mun.ca/PDFs/radical/AnalysisoftheClassesinChineseSociety.pdf Accessed on: 5 Mar. 2020.

MCKNIGHT, D. Populism Now!: the case for progressive populism paperback. Australian: University of New South Wales Press, 2018.

MOUFFE, C. For a Left Populism. Rio de Janeiro: Verso Books, 2018.

MUDDE, C.; KALTWASSER, C. R. Populism: a very short introduction. Oxford: Oxford University Press, 2017.

MÜlLER, J-W. What Is Populism? London: Penguin UK, 2017.

POSNER, E. A. Liberal Internationalism and the Populist Backlash. Public Law and Legal Theory Working Papers, v. 66, 2017.

QUIGLEY, H. S. Foreign concessions in chinese hands. 1928. Available in: https://www.foreignaffairs.com/articles/ china/1928-10-01/ foreign-concessions-chinese-hands Accessed on: 5 Mar. 2020.

RANSOME, A. The chinese purgle. Australian: Allen \& Unwin, Ltd, 1927. Available in: https:// mcgill.worldcat.org/title/chinese-puzzle/ oclc/2754703\&referer=brief_results Accessed on: 5 Mar. 2020.

ROBERTS, A. Is International Law International? Oxford: Oxford University Press, 2017.

RODILES, A. Is There a "Populist" International Law (in Latin America)? In: NIJMAN, J. E.; WERNER, W. G. (ed.). Netherlands Yearbook of International Law 2018. Berlin: TMC Asser Press, 2019. v. 49.

SCHEPPELE, K. L. The opportunism of populists and the defense of constitutional liberalism. German Law Journal, v. 20, n. 314, 2019.

SCHWÖBEL-PATEL, C. Populism, international law and the end of keep calm and carry on lawyering. In: NIJMAN, J. E.; WERNER, W. G. (ed.). Nether- lands Yearbook of International Law 2018. Berlin: TMC Asser Press, 2019. v. 49.

SHANGHAI ACADEMY OF SOCIAL SCIENCES I OF H. Wu Sa Yundong Shi Liao. Shangai: Shanghai Remin Press, 1981. v. 1.

TANG, Q. Treaty revision campaign of the Beijing Government, 1912-1928: out of the shadow of the 'Abrogation of Unequal Treaties'. Beijing: Social Sciences Academic Press, 2010.

THE SECOND HISTORICAL ARCHIVES OF CHINA. Wu Sa Yundong He Sheng Gang Bagong. Nanjing: Jiangsu Guji Press, 1985.

TSENG, Y-H. The termination of unequal treaties in international law: studies in comparative jurisprudence and Conventional Law of Nations. Pequin: The Commercial Press, Ltd, 1931. Available in: https://heinonline. org/HOL/P?h=hein.hoil/trmunq10001\&i=75 Accessed on: 3 Mar. 2020.

VON BERNSTORFF, J.; DANN, P. (ed.). The Battle for International Law: South-North perspectives on the Decolonization Era. Oxford: Oxford University Press, 2019.

WALKER, N. Populism and constitutional tension. International Journal of Constitutional Law, v. 17, n. 515, 2019.

WANG, M. Shanghai Hequhecong? Lun Nanjing Guomin Zhengfu Chuqi Yingmei de "Shanghai Wenti" Zhengce. Jindaishi Yanjiu, n. 105, 2015.

WANG, M. The publication and abandonment of the report of the hon: Richard Feetham in the context of changes in sino-british relations. Li Shi Yan Jiu, n. 83, 2012.

WILBUR, C. M. The Nationalist Revolution in China, $1923-$ 1928. Cambridge: Cambridge University Press, 1985.

WOODHEAD, H. G. W. (ed.). The China Year Book. China: Tientsin Press, 1928.

WUERTH, I. International Law in the Post-Human Rights Era. Texas Law Review, v. 96, n. 279, 2017.

XINHUA NEWS AGENCY. Shoubui Hankou, Jiujiang Yingrujie de Douzheng People's Daily. Beijing, 14 April 2007.

YONGJIN, Z. China in the International System, 1918-20: the middle kingdom at the periphery. London: Palgrave Macmillan UK, 1991. 
YSUI, S-C. The Influence of the Canton-Moscow Entente upon Sun Yat-Sen's Political Philosophy. Chinese Social and Political Science Review, v. 18, n. 96, 1934.

ZHONGHUA, et al. (ed). Zhongguo Gonghui Lishi Wenxian (1921.7-1927.7). China: Gongren Press, 1958. Available in: https://www.marxists.org/chinese/pdf/ history_of_international/china/g1.pdf Accessed on: 5 Mar. 2020. 
Para publicar na Revista de Direito Internacional, acesse o endereço eletrônico www.rdi.uniceub.br ou www.brazilianjournal.org.

Observe as normas de publicação, para facilitar e agilizar o trabalho de edição. 